\title{
Sub-grid scale representation of vegetation in global land surface schemes: implications for estimation of the terrestrial carbon sink
}

\author{
J. R. Melton and V. K. Arora \\ Canadian Centre for Climate Modelling and Analysis, Environment Canada, Victoria, BC, V8W 2Y2, Canada \\ Correspondence to: J. R. Melton (joe.melton.sci@gmail.com)
}

Received: 20 August 2013 - Published in Biogeosciences Discuss.: 17 October 2013

Revised: 6 January 2014 - Accepted: 8 January 2014 - Published: 21 February 2014

\begin{abstract}
Terrestrial ecosystem models commonly represent vegetation in terms of plant functional types (PFTs) and use their vegetation attributes in calculations of the energy and water balance as well as to investigate the terrestrial carbon cycle. Sub-grid scale variability of PFTs in these models is represented using different approaches with the "composite" and "mosaic" approaches being the two end-members. The impact of these two approaches on the global carbon balance has been investigated with the Canadian Terrestrial Ecosystem Model (CTEM v 1.2) coupled to the Canadian Land Surface Scheme (CLASS v 3.6). In the composite (singletile) approach, the vegetation attributes of different PFTs present in a grid cell are aggregated and used in calculations to determine the resulting physical environmental conditions (soil moisture, soil temperature, etc.) that are common to all PFTs. In the mosaic (multi-tile) approach, energy and water balance calculations are performed separately for each PFT tile and each tile's physical land surface environmental conditions evolve independently. Pre-industrial equilibrium CLASS-CTEM simulations yield global totals of vegetation biomass, net primary productivity, and soil carbon that compare reasonably well with observation-based estimates and differ by less than $5 \%$ between the mosaic and composite configurations. However, on a regional scale the two approaches can differ by $>30 \%$, especially in areas with high heterogeneity in land cover. Simulations over the historical period (1959-2005) show different responses to evolving climate and carbon dioxide concentrations from the two approaches. The cumulative global terrestrial carbon sink estimated over the 1959-2005 period (excluding land use change (LUC) effects) differs by around $5 \%$ between the two approaches (96.3 and 101.3 Pg, for the mosaic and composite approaches, respectively) and compares well with the
\end{abstract}

observation-based estimate of $82.2 \pm 35 \mathrm{PgC}$ over the same period. Inclusion of LUC causes the estimates of the terrestrial C sink to differ by $15.2 \mathrm{PgC}(16 \%)$ with values of 95.1 and $79.9 \mathrm{PgC}$ for the mosaic and composite approaches, respectively. Spatial differences in simulated vegetation and soil carbon and the manner in which terrestrial carbon balance evolves in response to LUC, in the two approaches, yields a substantially different estimate of the global land carbon sink. These results demonstrate that the spatial representation of vegetation has an important impact on the model response to changing climate, atmospheric $\mathrm{CO}_{2}$ concentrations, and land cover.

\section{Introduction}

Terrestrial ecosystem models (TEMs) or dynamic global vegetation models (DGVMs), with their associated land surface schemes (LSSs), are used in Earth system models (ESMs) to simulate the $\mathrm{CO}_{2}$ flux between the land surface and the atmosphere's lower boundary. An important application of TEMs and DGVMs has been to estimate the terrestrial biosphere's role in the uptake of anthropogenic carbon (Le Quéré et al., 2009; Huntzinger et al., 2012) and to quantify carbon emissions due to land use change (LUC) and changing climate (Arora and Boer, 2010).

Typically, LSSs use specified structural physical attributes of vegetation in their calculation of surface energy and water balance terms. These attributes include leaf area index, vegetation roughness height, rooting depth, fractional vegetation cover and canopy mass. When coupled to TEMs or DGVMs, vegetation is modelled as an interactive component and physical attributes of vegetation are simulated as a 


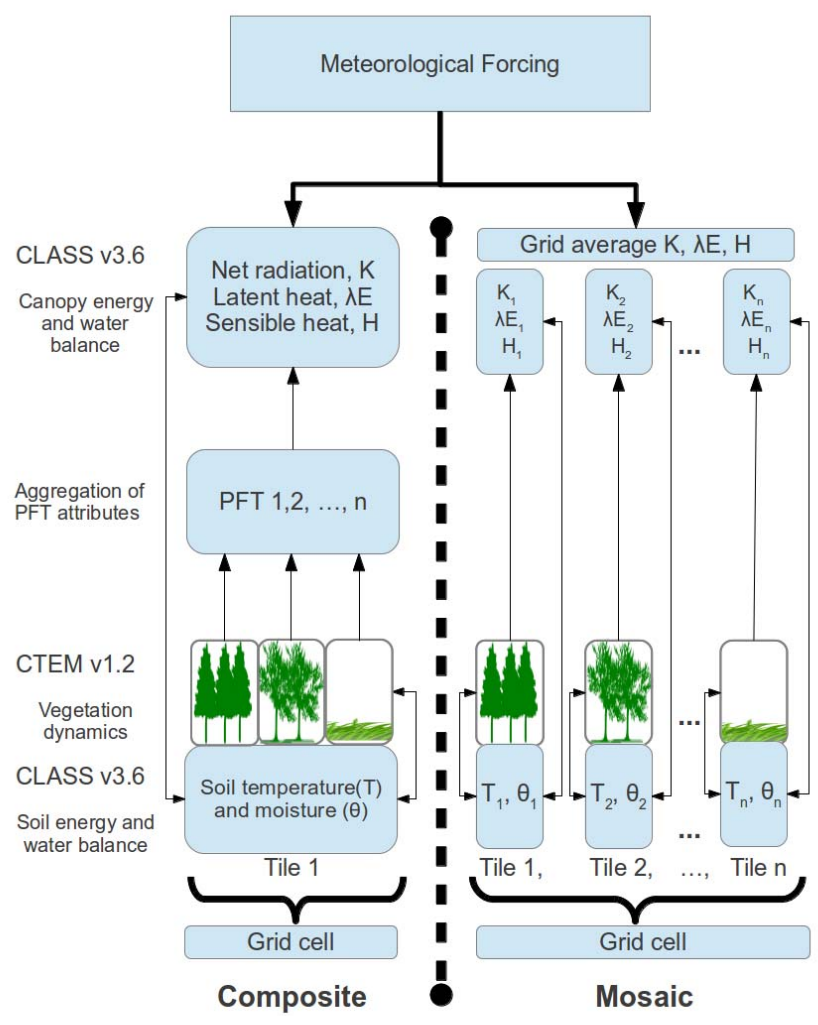

Fig. 1. Schematic representation of the composite and mosaic approaches for the coupling of CLASS v 3.6 and CTEM v 1.2 models in a stand-alone mode.

function of driving climate and atmospheric $\mathrm{CO}_{2}$ concentration $\left(\mathrm{CO}_{2}\right)$. Coupled LSSs and TEMs simulate fluxes of water, energy and $\mathrm{CO}_{2}$ at the atmosphere-land boundary. Vegetation in ESMs is commonly represented in terms of broad plant functional types (PFTs). Appropriate representation of these PFTs' spatial distribution presents a challenge to modellers, as the area of climate model grid cells is often on the order of $100000 \mathrm{~km}^{2}$. On these large scales, the spatial distribution of terrestrial vegetation can be extremely heterogeneous. For example, a grid cell with a land cover that is $20 \%$ treed and $80 \%$ herbaceous may represent a typical savannah landscape with intermittent trees, or a closed-canopy forest surrounded by prairie grasslands. In reality, these two landscapes represent greatly different physical and hydrological environments for the plants growing within them. Earth system models thus need to adopt a strategy that can accurately capture the vegetation dynamics due to sub-grid scale variability without incurring excessive computational cost. In response to this requirement, the Earth system modelling community has adopted three main approaches to represent sub-grid scale vegetation variability within LSS frameworks, which are termed: (i) composite, (ii) mosaic, and (iii) mixed (following Li and Arora, 2012).

The composite approach (left column of Fig. 1) assumes that structural (as mentioned above) and physiological at- tributes (e.g. stomatal conductance) of the PFTs present can be averaged across the grid cell (weighted by each PFT's fractional coverage) (Verseghy, 1991; Verseghy et al., 1993; Sitch et al., 2003). These grid-averaged values are then used in water- and energy balance calculations to obtain a gridaveraged physical state of the land surface. Thus, each PFT is exposed to the same environmental variables, such as canopy temperature, soil moisture, soil temperature, and net radiation.

The mosaic representation of the land surface uses separate "tiles" for each PFT (Koster and Suarez, 1992a) (right column of Fig. 1). Each tile simulates the energy and water balance based upon the interactions of the structural and physiological characteristics of its PFT with the driving climate, without regard to the conditions in the other tiles. As a result, the land surface state in each tile evolves independently with unique environmental variables with corresponding different simulated energy, water and $\mathrm{CO}_{2}$ fluxes. The tiles fluxes are then grid-averaged prior to interaction with the lower boundary of the atmosphere.

The composite and mosaic approaches can be considered as the two extremes of the manner in which spatial variability of vegetation is represented. We term other approaches that lie in between the mosaic and composite as "mixed". An example of the mixed approach uses the PFT vegetation attributes for calculations of the energy and water balance for each tile, but the soil moisture and temperature are gridaveraged at the end of each time step (Sellers et al., 1986; Dickinson et al., 1993; Oleson et al., 2010).

Different landscapes are better represented by one of the three approaches described above. Landscapes that are believed to be better suited to a composite representation include mixed deciduous broadleaf and evergreen needleleaf forests, as well as savannahs with sparse trees on grassland. The mosaic approach is suggested to better represent landscapes with a clear distinction between PFTs such as nonoverlapping cropland and closed-canopy forest. A mixed approach is usually chosen to reduce computational cost, not specifically to better represent the land surface. Commonly, a model is run with a globally constant application of either composite or mosaic approaches, without consideration of the particular observed vegetation structure of an individual grid cell.

The impact of the mosaic vs. the composite approach has been investigated with respect to the surface energy and hydrological balance (Koster and Suarez, 1992a, b; Molod and Salmun, 2002; Molod et al., 2003, 2004; Essery et al., 2003), however the impact on the carbon balance has received little attention. Li and Arora (2012) analyzed site-level (single grid cell) differences in simulated carbon pools and fluxes between composite and mosaic approaches at four locations (two boreal, one temperate, and one tropical) with the Canadian Land Surface Scheme (CLASS) version 3.4 (Verseghy, 2009) coupled to the Canadian Terrestrial Ecosystem Model (CTEM) version 1.0 (Arora, 2003; Arora and Boer, 2005). 
Their analysis was designed to generate the largest possible difference between the composite and mosaic approaches, as a form of sensitivity test, thus they used an idealized PFT fractional coverage of $50 \%$ for each of the two dominant PFTs present at each location. Li and Arora (2012) reported that the primary energy fluxes were relatively insensitive to the vegetation representation, with less than $5 \%$ difference between the two approaches. However, the carbon fluxes and pool sizes varied by as much as $46 \%$ on a grid-averaged basis. Given that their simulations were intended to determine the largest influence on a site level, it is difficult to predict how important the vegetation configuration strategy is at a global scale, with realistic PFT fractional coverage, and under changing $\mathrm{CO}_{2}$, climate, and land use. Here, we expand on the work of Li and Arora (2012) by studying the impact of the manner in which sub-grid scale variability of vegetation is represented on the global terrestrial carbon balance. In addition, we investigate the model's response to historical changes in $\left(\mathrm{CO}_{2}\right)$, climate, and land cover when using the composite and mosaic approaches.

\section{Methods}

\subsection{Description of the CLASS and CTEM models}

The CLASS-CTEM results presented here were generated from coupling of the CLASS (v. 3.6) (Verseghy, 2012) and CTEM (v. 1.2) models. Slightly older versions of both models are currently implemented in the second-generation Canadian Centre for Climate Modelling and Analysis Earth System Model (CanESM2) (Arora et al., 2011), but are used in an offline configuration here, driven with observationbased climate, to allow for simpler interpretation.

CLASS operates on a half-hourly time step driven with atmospheric forcing data (downwelling longwave and shortwave radiation, precipitation, air pressure, specific humidity, wind speed, and air temperature) and calculates the energy and water balances of the soil, snow, and vegetation canopy components. CLASS includes three soil layers of thickness: $0.10,0.25$, and up to $3.75 \mathrm{~m}$ (the depth of the third layer is dependent on the grid-cell soil depth to bedrock from Zobler, 1986). The temperature and liquid and frozen moisture contents are simulated for each soil layer. CLASS also simulates, when snow is present, the physical characteristics (mass, density, albedo, liquid water content, and temperature) of one snow layer of a prognostically determined depth. Within a single tile, surface flux calculations are performed on tile sub-regions of (as required): (i) bare soil, (ii) vegetation covered ground, (iii) bare soil with snow cover, and (iv) vegetation over snow. CLASS performs energy and water balance calculations for four PFTs: needleleaf trees, broadleaf trees, crops, and grasses (short vegetation). Each PFT has prescribed structural attributes associated with it, such as leaf area index (LAI), plant height (roughness length), and root- ing depth. However, when coupled to CTEM, these variables are dynamically modelled by CTEM and passed to CLASS.

CTEM simulates terrestrial ecosystem processes for nine PFTs that are directly related to the four CLASS PFTs. Needleleaf trees are separated into evergreen and deciduous; broadleaf trees into evergreen, cold deciduous, and drought/dry deciduous; and crops and grasses are separated into $\mathrm{C}_{3}$ and $\mathrm{C}_{4}$. In the version used here, CTEM simulates the processes of photosynthesis, autotrophic and heterotrophic respiration, carbon allocation, phenology, turnover, and land use change.

CTEM operates on a daily time step (excluding the photosynthesis, leaf respiration, and canopy conductance calculations which are performed on the CLASS time step). The photosynthesis and respiration (autotrophic and heterotrophic) schemes of CTEM are described in Arora (2003). Positive net primary productivity (NPP) is allocated into three live carbon pools (roots, stems, and leaves). The proportional allocation to each of these pools is influenced by the leaf phenological, light and root water status of the plant (Arora and Boer, 2005). Turnover and mortality reduces the live carbon stock and contributes to two dead carbon pools (litter and soil organic matter). The disturbance (fire) module was not used in the simulations presented here.

The version of CTEM used here ( $\mathrm{v}$ 1.2) differs from the previously published version of CTEM (v. 1.0 Arora, 2003; Arora and Boer, 2005) in: (i) its capability to perform both mosaic and composite simulations of the land surface under LUC; (ii) adjustments to photosynthesis parameters including maximum photosynthetic rate, $V_{\mathrm{c}, \max }$, (Rogers, 2013); and (iii) adjustments to leaf maintenance and respiration rate parameters (see Table A1).

\subsection{Carbon budget equations}

The vertically integrated globally averaged carbon budget equation for the atmosphere can be represented as

$$
\frac{\mathrm{d} H_{\mathrm{A}}}{\mathrm{d} t}=E_{\mathrm{F}}-F_{\mathrm{O}}-F_{\mathrm{L}}=\left(E_{\mathrm{F}}+E_{\mathrm{LUC}}\right)-F_{\mathrm{O}}-F_{\mathrm{Ln}},
$$

where $H_{\mathrm{A}}$ is the global atmospheric carbon burden $(\mathrm{Pg} \mathrm{C})$, $F_{\mathrm{O}}$ and $F_{\mathrm{L}}$ are the atmosphere-ocean and atmosphere-land $\mathrm{CO}_{2}$ fluxes $\left(\mathrm{PgCyr}^{-1}\right)$, respectively, and $E_{\mathrm{F}}$ is the anthropogenic fossil fuel emissions $\left(\mathrm{PgCyr}^{-1}\right)$. The global net atmosphere-land $\mathrm{CO}_{2}$ flux $\left(F_{\mathrm{L}}=F_{\mathrm{Ln}}-E_{\mathrm{LUC}}\right)$, assumed positive into the land, in CLASS-CTEM is the result of natural $\mathrm{CO}_{2}$ flux $\left(F_{\mathrm{Ln}}\right)$ and LUC emissions $\left(E_{\mathrm{LUC}}\right)$ associated with changes in land cover (with the convention of positive into the atmosphere). The curly braces around the LUC term symbolize the LUC term to be made up of many different LUC processes. The globally averaged land carbon budget is represented as

$$
\begin{aligned}
& F_{\mathrm{L}}=\frac{\mathrm{d} H_{\mathrm{L}}}{\mathrm{d} t}=\frac{\mathrm{d} H_{\mathrm{V}}}{\mathrm{d} t}+\frac{\mathrm{d} H_{\mathrm{S}}}{\mathrm{d} t} \\
& =\left(\mathrm{GPP}-R_{\mathrm{A}}\right)-R_{\mathrm{H}}-E_{\mathrm{LUC}}=\mathrm{NPP}-R_{\mathrm{H}}-E_{\mathrm{LUC}},
\end{aligned}
$$


where $H_{\mathrm{L}}=H_{\mathrm{V}}+H_{\mathrm{S}}$, represents the global land carbon mass, which includes the live vegetation biomass, $H_{\mathrm{V}}$, and the dead carbon in the soil and litter pools, $H_{\mathrm{S}}$. GPP is gross primary productivity, which yields NPP after autotrophic respiration $\left(R_{\mathrm{A}}\right)$ is accounted for. $R_{\mathrm{H}}$ is heterotrophic respiration. When land cover is not changing, the term $E_{\mathrm{LUC}}$ is zero and $F_{\mathrm{L}}=F_{\mathrm{Ln}}$ represents net ecosystem productivity (NEP). In the presence of LUC and other disturbances (if any), the term $F_{\mathrm{L}}$ represents net biome productivity (NBP); for more discussion on the difference between NEP and NBP see (Chapin et al., 2006). Integrating Eq. (2) gives the change in total land carbon with respect to the cumulative landatmosphere $\mathrm{CO}_{2}$ flux $\left(\tilde{F}_{\mathrm{L}}\right)$ :

$$
\begin{aligned}
\tilde{F}_{\mathrm{L}} & =\int_{t_{o}}^{t} F_{\mathrm{L}} \mathrm{d} t=\Delta H_{\mathrm{L}}=\Delta H_{\mathrm{V}}+\Delta H_{\mathrm{S}} \\
& =\int_{t_{o}}^{t} \mathrm{NPP} \mathrm{d} t-\int_{t_{o}}^{t} R_{\mathrm{H}} \mathrm{d} t-\int_{t_{o}}^{t} E_{\mathrm{LUC}} \mathrm{d} t \tilde{F}_{\mathrm{L}}=\tilde{F}_{\mathrm{Ln}}-\tilde{E}_{\mathrm{LUC}}
\end{aligned}
$$

where the terms $\tilde{F}_{\mathrm{Ln}}$ and $\tilde{E}_{\mathrm{LUC}}$ represent cumulative NEP and cumulative LUC emissions, respectively.

\subsection{Land use change}

In CLASS-CTEM, LUC emissions are treated in a fully interactive manner, where an increase in crop area occurs through deforestation/clearing of natural vegetation and a reduction in the $H_{\mathrm{V}}$ of natural woody or herbaceous vegetation (see Arora and Boer, 2010). When crop area expands into the natural vegetated areas of the grid cell, as determined by the HYDE v 3.1 data set (Hurtt et al., 2011), the biomass removed, $L\left(\mathrm{~kg} \mathrm{~cm}^{-2}\right)$, is divided into three components such that $L=L_{\mathrm{A}}+L_{\mathrm{S}}+L_{\mathrm{D}}$. The first component, $L_{\mathrm{A}}$, is combusted during clearing, or used immediately for fuel wood, and emitted to the atmosphere as $\mathrm{CO}_{2}$; the second component, $L_{\mathrm{S}}$, is assigned to pulp and paper products, or left in place as slash; while the final component, $L_{\mathrm{D}}$, is used for durable wood products. The fraction of $L$ for each component $\left(L_{\mathrm{A}}, L_{\mathrm{S}}\right.$ or $\left.L_{\mathrm{D}}\right)$ depends on whether the PFT is woody or herbaceous and the aboveground vegetation biomass density (see Table 1 in Arora and Boer, 2010). To approximate the lifetimes of the $L_{\mathrm{S}}$ and $L_{\mathrm{D}}$ components, these components are allocated to the litter and soil carbon pools, respectively. As a result the carbon that is removed from live vegetation is emitted to the atmosphere either immediately $\left(L_{\mathrm{A}}\right)$, or with some delay depending on the decomposition rate of the litter or soil C pools. Crop PFT biomass is annually transferred to the soil litter pool $\left(L_{\mathrm{S}}\right)$ when the crop has matured (signified by leaf area index reaching $3.5 \mathrm{~m}^{2} \mathrm{~m}^{-2}$ for $C_{3}$ crops and $4.5 \mathrm{~m}^{2} \mathrm{~m}^{-2}$ for $C_{4}$ crops). This approach allows LUC impacts to influence all aspects of the terrestrial carbon budget including vegetation, litter and soil carbon pools and fluxes. The emissions of carbon due to LUC are evident in the $E_{\mathrm{LUC}}$ term as direct $\mathrm{CO}_{2}$ emissions but also in increased litter and soil C pool sizes, and subsequently, fluxes. When crop area fraction in a grid cell decreases, the fraction under natural vegetation is increased, which reduces the biomass density, causing the vegetation to uptake more carbon until it reaches
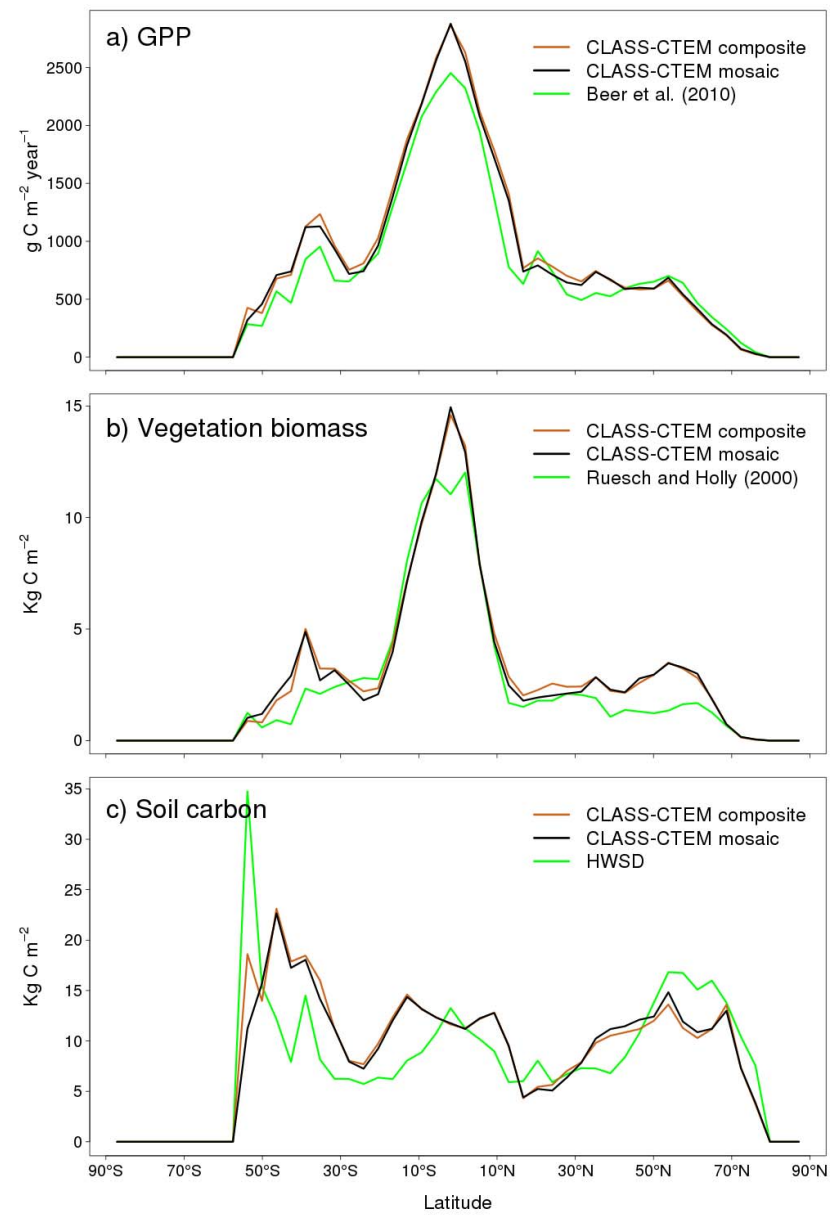

Fig. 2. Comparison of simulated zonally averaged (a) GPP, (b) vegetation biomass, and (c) soil carbon with observation-based estimates. The CLASS-CTEM results from the simulations using composite and mosaic configurations are averaged over the 1996-2005 period and are from the Climate $+\mathrm{CO}_{2}+$ LUC simulation.

a new equilibrium, creating the land-use-related carbon sink that is, for example, associated with abandonment of croplands. In practice, $E_{\mathrm{LUC}}$ is not straightforward to diagnose and at least two simulations are required. As in McGuire et al. (2001) and Arora and Boer (2010), for example, we diagnose $E_{\mathrm{LUC}}$ as the difference in atmosphere-land $\mathrm{CO}_{2}$ flux from simulations with and without LUC.

\subsection{Model inputs}

All CLASS-CTEM simulations were performed at the Gaussian $96 \times 48$ grid cell resolution (approximately $3.75^{\circ} \times$ $3.75^{\circ}$ ) and all inputs were interpolated to this resolution. Climate forcing was obtained by disaggregation of the CRUNCEP v. 4 data set (Viovy, 2012) (1901-2010) from its native 6-hourly values to a half-hourly time step. Shortwave radiation was diurnally interpolated based on day of year and latitude, with the maximum value occurring at solar noon. 
Table 1. CLASS-CTEM simulations performed for the composite and mosaic configurations. For the transient simulations (last four listed below), the simulation years of 1861-1900 were forced with climate from 1901 to 1940; simulation years 1901-2005 were forced with climate years from 1901 to 2005 .

\begin{tabular}{llll}
\hline Simulation name & Climate years & $\begin{array}{l}\text { Atmospheric } \\
\mathrm{CO}_{2} \text { years }\end{array}$ & $\begin{array}{l}\text { Land cover } \\
\text { years }\end{array}$ \\
\hline Equilibrium & $1901-1940$ (cycling) & 1861 & 1861 \\
Climate only & $1901-1940$ then 1901-2005 & 1861 & 1861 \\
Climate $+\mathrm{CO}_{2}$ & $1901-1940$ then 1901-2005 & $1861-2005$ & 1861 \\
Climate $+\mathrm{LUC}_{\text {Climate }+\mathrm{CO}_{2}+\mathrm{LUC}}$ & $1901-1940$ then 1901-2005 & 1861 & $1861-2005$ \\
\hline
\end{tabular}

Longwave radiation was uniformly distributed over the $6 \mathrm{~h}$ period. Surface temperature, wind speed, surface pressure, and specific humidity were linearly interpolated. The total $6 \mathrm{~h}$ precipitation amount was used to determine the number of wet half-hour time steps following Arora (1997). The total $6 \mathrm{~h}$ amount was then distributed amongst the wet time steps.

Soil texture information was adapted from Zobler (1986) with soil texture within each grid cell kept the same for both composite and mosaic configurations. For the historical 1850-2005 period, the $\left(\mathrm{CO}_{2}\right)$ is based on phase 5 of the Coupled Model Intercomparison Project (CMIP5) data set (Meinshausen et al., 2011). The changes in fractional coverage of non-crop PFTs are inferred based on the changes in crop area following the HYDE v 3.1 data set (Hurtt et al., 2011) using the linear interpolation approach of Arora and Boer (2010). The resulting transient land cover for the period 1850-2005 has also been used in CanESM2's simulations for CMIP5 (Arora et al., 2011).

\subsection{Simulations}

Results from five simulations are presented for both the mosaic and composite approaches (Table 1). The pre-industrial equilibrium spin-ups, corresponding to the year 1861, form the starting point for each of the four transient historical runs (1861-2005), which were driven with different combinations of $\mathrm{CO}_{2}$, climate and LUC forcings. These include: (i) evolving climate with fixed 1861 land cover and $\left(\mathrm{CO}_{2}\right)$ ("Climate only"), (ii) evolving climate and $\mathrm{CO}_{2}$ with fixed 1861 land cover ("Climate $+\mathrm{CO}_{2}$ "), (iii) evolving climate and land cover with fixed $1861\left(\mathrm{CO}_{2}\right)$ ("Climate + LUC"), and (iv) evolving climate, $\left(\mathrm{CO}_{2}\right)$, and land cover ("Climate $+\mathrm{CO}_{2}+$ LUC"). Since the CRU-NCEP climate data does not extend back past 1901, for the period 1861-1900 we use the climate of 1901-1940. We also do not extend past 2005 as that is the last year in the HYDE v. 3 data set as used in the CMIP5 simulations. For most of the results presented here, we limit our analysis to the 1959-2005 period for ease of comparison with the results of other dynamic vegetation models and the estimated terrestrial $\mathrm{C}$ land sink as summarized in Le Quéré et al. (2013).
The pre-industrial equilibrium run used a constant, globally uniform $\left(\mathrm{CO}_{2}\right)$ of $286.37 \mathrm{ppm}$ corresponding to observed atmospheric concentration in the year 1861 (Meinshausen et al., 2011) with PFT fractional coverage corresponding to the year 1861 and climate from 1901 to 1940 cycled over repeatedly until model pools reached equilibrium (Table 1). Equilibrium is assumed to have been attained when net ecosystem productivity, $F_{\mathrm{Ln}}$, varies less than $0.001 \%$ of NPP averaged across the final $40 \mathrm{yr}$ of the simulation. Composite and mosaic simulations were spun up separately.

\section{Results}

\subsection{Comparison to observationally based data sets}

The pre-industrial equilibrium simulations global totals for primary model outputs are listed in Table 2 . Both the composite and mosaic approaches simulate global totals of GPP, NPP, soil respiration, vegetation biomass, litter mass, and soil carbon in line with observation-based estimates and previous modelling studies of the pre-industrial period (Table 2). For these global sums, the difference between the composite vs. mosaic approach is minor (maximum 4.6\%). Overall, the composite approach yields higher productivity and respiratory fluxes, and higher vegetation and soil carbon pools, than the mosaic approach.

Zonally, CLASS-CTEM reproduces reasonable patterns of GPP, vegetation biomass and soil carbon as compared to observation-based data sets for contemporary conditions (Fig. 2). While the CLASS-CTEM results ("Climate $+\mathrm{CO}_{2}+$ LUC") in Sect. 2 include the influence of LUC, they do not include biomass burning (wildfires) as a disturbance agent, which would influence the model results in some fire-prone regions. An observation-based GPP estimate from Beer et al. (2010) is used for comparison with CLASS-CTEM outputs. Beer et al. (2010) analyze the ground-based carbon flux tower observations from ca. 250 stations using diagnostic models to extrapolate them to the global scale for the 1998-2005 period. Mean zonal GPP simulated by CLASS-CTEM displays the same general pattern as the Beer et al. (2010) data set (Fig. 2a). 
CLASS-CTEM simulates slightly higher values at the equator and below about $35^{\circ} \mathrm{S}$ than Beer et al. (2010), but slightly lower values for latitudes $>45^{\circ} \mathrm{N}$ and around $15^{\circ} \mathrm{N}$. The composite and mosaic CLASS-CTEM zonal GPP shows only small differences around $10-30^{\circ} \mathrm{N}$ and around 20 $40^{\circ} \mathrm{S}$, with a higher GPP simulated when using the composite approach.

For zonally averaged vegetation biomass (Fig. 2b), CLASS-CTEM simulates an equatorial peak in vegetation biomass slightly higher than the Ruesch and Holly (2008) data set for both approaches. This data set is based upon remotely sensed vegetation cover (Global Land Cover 2000 Project, GLC2000) and IPCC methods for estimating carbon stocks at the national level. For latitudes $>30^{\circ} \mathrm{N}$ and $<30^{\circ} \mathrm{S}$, CLASS-CTEM simulates a higher mean vegetation biomass than Ruesch and Holly (2008) with a prominent peak around $45^{\circ} \mathrm{S}$. The mosaic and composite approaches differ little in zonal mean vegetation biomass except for small differences around $10-30^{\circ} \mathrm{N}$ where the composite approach has a noticeably higher value. The methods employed to create the Ruesch and Holly (2008) data set are not directly linked to ground-based measures of carbon stocks and have also not been validated with field data. The data set may underestimate vegetation biomass at high latitudes. For example, its vegetation biomass values are less than half that of inventory based estimates for British Columbia, Canada (Peng et al., 2013).

The CLASS-CTEM mosaic and composite approaches' zonally averaged soil carbon is compared to the Harmonized World Soils Dataset (HWSD) (FAO, 2012) in Fig. 2c. The HWSD is more reliable for southern and Eastern Africa, Latin America and the Caribbean, and central and eastern Europe. It is considered less reliable for North America, Australia, areas of West Africa and South Asia (FAO, 2012). While the zonal distribution of simulated soil carbon is broadly similar to observation-based HWSD estimates, some differences remain. Between 45-70 N, CLASS-CTEM simulates appreciably less soil carbon than the HWSD, with values around $15^{\circ} \mathrm{N}$, and below $50^{\circ} \mathrm{S}$ also lower (below $50^{\circ} \mathrm{S}$ has little landmass thus the large value in the HWSD is likely the result of high values in relatively few grid cells). Some of the difference between CLASS-CTEM and HWSD is due to the fact that peatlands, which contain high amounts of organic carbon, are not presently simulated by CLASSCTEM. This is especially noticeable in the region of 45$70^{\circ} \mathrm{N}$. CLASS-CTEM simulates appreciably more soil carbon around $30-50^{\circ} \mathrm{N}$ and in most of the Southern Hemisphere.

\subsection{Spatial differences between the approaches}

Figure $3 a-c$ shows the spatial distribution of simulated GPP, vegetation biomass and soil $\mathrm{C}$ mass from the pre-industrial equilibrium simulation when using the mosaic approach. The corresponding spatial differences between the composite and mosaic approaches are shown in Fig. 3d-f. The major regions of difference for vegetation biomass and GPP, which can be $>30 \%$, include Southeast Asia, the Pampas region in Argentina, the west coast of North America, southeast US, northern mainland Europe, and Mexico (Fig. 3d and e). In each of those regions, the composite simulation calculates higher GPP and vegetation biomass. The mosaic approach yields higher GPP and vegetation biomass for some regions, such as eastern Canada, China, the central US, and Patagonia, however the magnitude of the difference is smaller than for the regions where the composite approach simulates larger values. The simulated soil carbon mass differences between the mosaic and composite runs (Fig. 3f) follow a similar pattern to the differences in vegetation biomass with Southeast Asia, the Pampas of Argentina, the west coast of North America, northwest mainland Europe, and southeast Australia, simulated to have higher soil carbon mass in the simulation using the composite approach. Some other regions show contrasting patterns between vegetation biomass and soil carbon, including the southeast US, the Chilean coast, the Baltics, and western Russia, although the differences are relatively small.

\subsection{Transient historical simulations}

Four simulations were performed to investigate the effect of using the composite versus mosaic approach on the historical terrestrial carbon budget. The simulations were driven with different combinations of $\mathrm{CO}_{2}$, climate and LUC forcings (as described in Sect. 2.5 and Table 1): (i) Climate only, (ii) Climate $+\mathrm{CO}_{2}$, (iii) Climate $+\mathrm{LUC}$, and (iv) Climate $+\mathrm{LUC}+\mathrm{CO}_{2}$.

In Fig. $4 \mathrm{a}$, simulated $\tilde{F}_{\mathrm{L}}$ from the Climate $+\mathrm{CO}_{2}$ simulation (using both the composite and mosaic approaches) is compared to an observation-based estimate and simulations from eight other TEMs/DGVMs (as presented in Le Quéré et al., 2013). The Climate $+\mathrm{CO}_{2}$ simulation does not include land use change, thus $\tilde{F}_{\mathrm{L}}=\tilde{F}_{\mathrm{Ln}}$, which essentially represents cumulative NEP. $\tilde{F}_{\mathrm{Ln}}$ is also referred to as the residual terrestrial $\mathrm{C}$ sink, whose value can be determined as the residual of other observation-based terms in Eq. (1). The observation-based estimate of $\tilde{F}_{\mathrm{Ln}}$ from Le Quéré et al. (2013) in Fig. 4a is their estimate of the residual terrestrial $\mathrm{C}$ sink after accounting for fossil fuel and LUC emissions, change in atmospheric $\mathrm{C}$ burden and the ocean $\mathrm{C}$ sink. This does not include gross land $\mathrm{C}$ sinks directly resulting from LUC (e.g. regrowth of vegetation), but does include the influence of $\mathrm{CO}_{2}$ fertilization, nitrogen deposition, and other climate change effects such as changes to growing season length. Simulated $\tilde{F}_{\mathrm{Ln}}$, over the 1959-2005 period, does not differ greatly between the mosaic $(96.3 \mathrm{PgC})$ and composite $(101.3 \mathrm{PgC})$ approaches, while it compares reasonably with the observation-based estimate $(82.2 \pm 35 \mathrm{PgC})$ from Le Quéré et al. (2013) and lies within the range of other TEMs/DGVMs. 

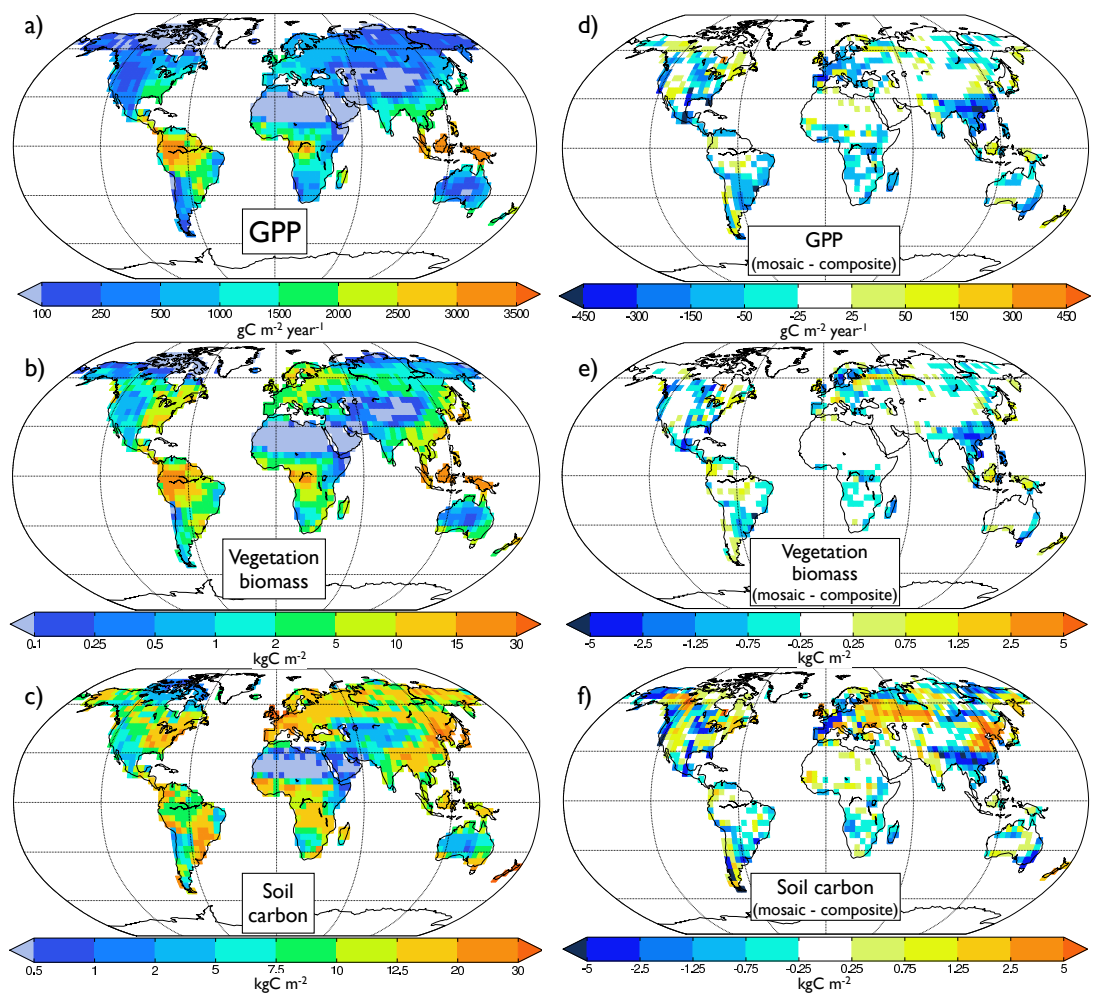

Fig. 3. Pre-industrial equilibrium CLASS-CTEM results using the mosaic approach for (a) GPP, (b) vegetation biomass, and (c) soil carbon mass. The difference between the mosaic and composite approach is shown in the right-hand column for (d) GPP, (e) vegetation biomass, and (f) soil carbon mass. Positive values indicate that the values from the mosaic approach are larger; negative values indicate that the composite approach yields larger values.

Table 2. Results from the pre-industrial equilibrium simulations using the composite and mosaic model configurations. Values are a 40 yr average at the end of model spin-up. The spin-up cycled over climate years 1901-1940 with year 1861 atmospheric $\left(\mathrm{CO}_{2}\right)$ and land cover.

\begin{tabular}{|c|c|c|c|c|c|}
\hline Variable & & Model outputs & & Preindustrial values from & Other modern \\
\hline & Composite & Mosaic & Difference $(\%)$ & modelling studies & estimate \\
\hline Gross primary productivity $\left(\mathrm{PgCyr}^{-1}\right)$ & 121.8 & 117.3 & 3.8 & 134.0 (Gerber et al., 2004) & $\begin{array}{l}\text { ca. } 125 \text { (Zhao et al., 2006) }{ }^{\mathrm{a}} \\
123 \pm 8^{\mathrm{b}} \text { (Beer et al., 2010) }\end{array}$ \\
\hline Net primary productivity $\left(\mathrm{PgCyr}^{-1}\right)$ & 61.0 & 58.5 & 4.3 & $\begin{array}{l}64.0 \text { (Sitch et al., 2003), 50-70 } \\
\text { (Friedlingstein et al. , 2006) }\end{array}$ & $\begin{array}{l}59.9 \text { (Ajtay et al., 1979), } \\
62.6 \text { (Saugier et al., 2001), } \\
56.6 \text { (Running et al., 2004) }\end{array}$ \\
\hline Litter respiration $\left(\mathrm{PgC} \mathrm{yr}^{-1}\right)$ & 41.8 & 40.1 & 4.2 & & \\
\hline Soil carbon respiration $\left(\mathrm{PgC} \mathrm{yr}^{-1}\right)$ & 19.2 & 18.4 & 4.3 & & \\
\hline Soil respiration (litter + soil C) $\left(\mathrm{Pg} \mathrm{Cyr}^{-1}\right)$ & 61.0 & 58.5 & 4.1 & $\begin{array}{l}68 \pm 4 \text { (Raich and Schlesinger, } \\
1992) \text {, } \\
76.5 \text { (Raich and Potter, 1995) }\end{array}$ & \\
\hline Vegetation biomass (Pg C) & 530 & 507 & 4.6 & 932 (Sitch et al., 2003) & 446 (Ruesch and Holly, 2008) ${ }^{\mathrm{c}}$ \\
\hline Litter mass (Pg C) & 97 & 94 & 2.9 & 171 (Sitch et al., 2003) & 90 (Ajtay et al., 1979) \\
\hline Soil carbon mass $(\operatorname{Pg} C)$ & 1409 & 1404 & 0.03 & 1670 (Sitch et al., 2003) & $\begin{array}{l}\text { 1400-1600 (Schlesinger, 1977), } \\
1395 \text { (Post et al., 1982), } \\
1348 \text { (FAO, 2012) }\end{array}$ \\
\hline
\end{tabular}

${ }^{a}$ MODIS-derived LAI driven with NCEP reanalysis. ${ }^{b}$ Estimate for modern-day, which includes the effects of elevated $\mathrm{CO}_{2}$ and anthropogenic land use. ${ }^{\mathrm{c}}$ Interpolated to $\mathrm{T} 47$ resolution and using the same land mask as CLASS-CTEM.

Introducing changes in land cover imply that the term $E_{\mathrm{LUC}}$ is not zero and the cumulative atmosphere-land $\mathrm{CO}_{2}$ flux is reduced $\left(\tilde{F}_{\mathrm{L}}=\tilde{F}_{\mathrm{Ln}}-\tilde{E}_{\mathrm{LUC}}\right)$ to yield the cumulative NBP. Note that our definition of NBP, in the context of CLASS-CTEM, does not include the effect of distur- bance agents such as fire, insects, management-climate interactions, and nitrogen dynamics. Figure $4 \mathrm{~b}$ shows the cumulative deforested biomass in the Climate $+\mathrm{LUC}+\mathrm{CO}_{2}$ simulation $(L)$ when using the composite and mosaic approaches over the 1959-2005 period. The deforested biomass 

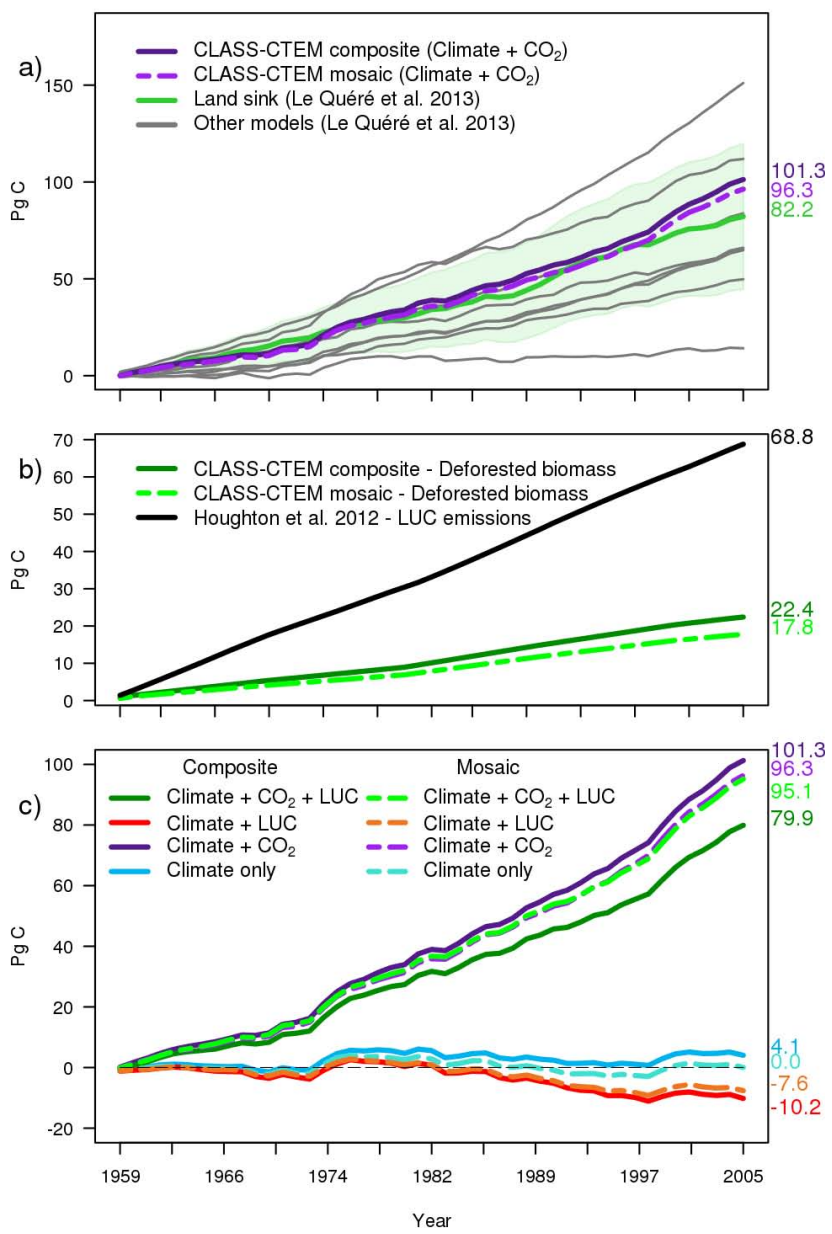

Fig. 4. CLASS-CTEM results from the transient simulations over the 1959-2005 period using the composite and mosaic approaches. (a) The simulated cumulative atmosphere-land $\mathrm{CO}_{2}$ flux $\left(\tilde{F}_{\mathrm{Ln}}\right)$ from the Climate $+\mathrm{CO}_{2}$ simulation in comparison with other terrestrial vegetation model estimates and the estimated residual land sink from Le Quéré et al. (2013). None of the model results include LUC and all simulations/estimates account for changing climate and atmospheric $\left(\mathrm{CO}_{2}\right)$. (b) Deforested biomass from the Climate $+\mathrm{CO}_{2}+$ LUC simulation alongside the bookkeeping-based estimate of LUC emissions from Houghton et al. (2012). (c) Results from the four different transient simulations using different combinations of climate, $\left(\mathrm{CO}_{2}\right)$, and LUC forcings. The model setup for each run is described in Sect. 2.5 and Table 1. Negative and positive $\tilde{F}_{\mathrm{L}}$ and $\tilde{F}_{\mathrm{Ln}}$ values indicate net carbon release from the land surface to the atmosphere and uptake by the land surface, respectively.

is somewhat higher in the composite approach $(22.4 \mathrm{Pg} \mathrm{C})$ than when using the mosaic approach $(17.8 \mathrm{PgC})$ because of its higher vegetation biomass. However, these values of deforested biomass are much lower than the Houghton et al. (2012) estimate of LUC emissions (68.8 Pg C) over the same period (calculated from original data available at http://cdiac. ornl.gov/trends/landuse/houghton/houghton.html). The LUC emissions from Houghton et al. (2012) are based on a "book- keeping" approach where changes in cropland and pasture area, wood harvesting and logging, and shifting cultivation are accounted for via transfer to pools with prescribed turnover rates. Our LUC parametrization does not take into account wood harvesting or logging, shifting cultivation and conversion to pasture.

Figure $4 \mathrm{c}$ compares cumulative atmosphere-land $\mathrm{CO}_{2}$ flux $\tilde{F}_{\mathrm{L}}$ from all four simulations when using both the mosaic and composite approaches. Over the 1959-2005 period, the Climate only simulation shows no strong net emission, or uptake, of carbon by the land surface when using the mosaic approach $(0.0 \mathrm{PgC})$ and a slight carbon uptake by the land surface when the composite approach is used $(4.1 \mathrm{PgC})$. The Climate + LUC simulations give a net land $\mathrm{C}$ source with mosaic and composite cumulative NBP values of 7.6 Pg C and 10.2 PgC, respectively. Climate $+\mathrm{CO}_{2}$ simulations show a large terrestrial carbon uptake of 96.3 $\mathrm{PgC}$ and 101.3 PgC for mosaic and composite approaches, respectively, as also seen in Fig. 4a. Finally, the Climate $+\mathrm{LUC}+\mathrm{CO}_{2}$ simulation reduces the estimated terrestrial $\mathrm{C}$ sink slightly to $95.1 \mathrm{PgC}$ (1\% reduction compared to the Climate $+\mathrm{CO}_{2}$ simulation) when using the mosaic approach, but a much stronger reduction is seen in the composite approach $(79.9 \mathrm{PgC} ; 21 \%$ reduction compared to the $\mathrm{Cli}-$ mate $+\mathrm{CO}_{2}$ simulation) at the end of the 1959-2005 period. Overall, the difference between the composite and mosaic approaches, for global carbon uptake, is most pronounced for the Climate $+\mathrm{CO}_{2}+\mathrm{LUC}$ simulation. Diagnosing cumulative LUC emissions, $\tilde{E}_{\mathrm{LUC}}$, as the difference between cumulative atmosphere-land $\mathrm{CO}_{2}$ flux between the Climate $+\mathrm{CO}_{2}$ and Climate $+\mathrm{CO}_{2}+$ LUC simulations, in a manner similar to McGuire et al. (2001) and Arora and Boer (2010), we obtain $\tilde{E}_{\mathrm{LUC}}$ as $21.4 \mathrm{Pg} \mathrm{C}$ and $1.2 \mathrm{PgC}$ for the composite and mosaic approaches, respectively.

Geographical distributions of the difference in atmosphere-land $\mathrm{CO}_{2}$ flux $\left(F_{\mathrm{L}}\right)$ averaged over the period 1959-2005 between the mosaic and composite approaches are shown in Fig. 5 from the Climate $+\mathrm{CO}_{2}$ (panel a) and Climate $+\mathrm{CO}_{2}+\mathrm{LUC}$ (panel b) simulations. For the Climate $+\mathrm{CO}_{2}$ simulation (Fig. 5a) the difference between the mosaic and composite approaches is greatest in the Pampas region of Argentina, Southeast Asia and southern China, northern India, Tanzania, and parts of Mexico where the composite approach simulates a larger $\mathrm{C}$ sink. Although there are some regions (including the American Midwest and parts of Scandinavia and western Russia) where the mosaic approach yields a larger $\mathrm{C}$ sink, in the Climate $+\mathrm{CO}_{2}$ simulation, for most regions the sink is larger when the composite approach is used. When LUC is considered (Fig. 5b) the general pattern shifts to a larger uptake of $\mathrm{C}$ in the mosaic approach rather than in the composite approach (as in Fig. 5a), but the regions with the largest difference between the composite and mosaic approaches remain the same (e.g. parts of Argentina, southern China, and Mexico). 


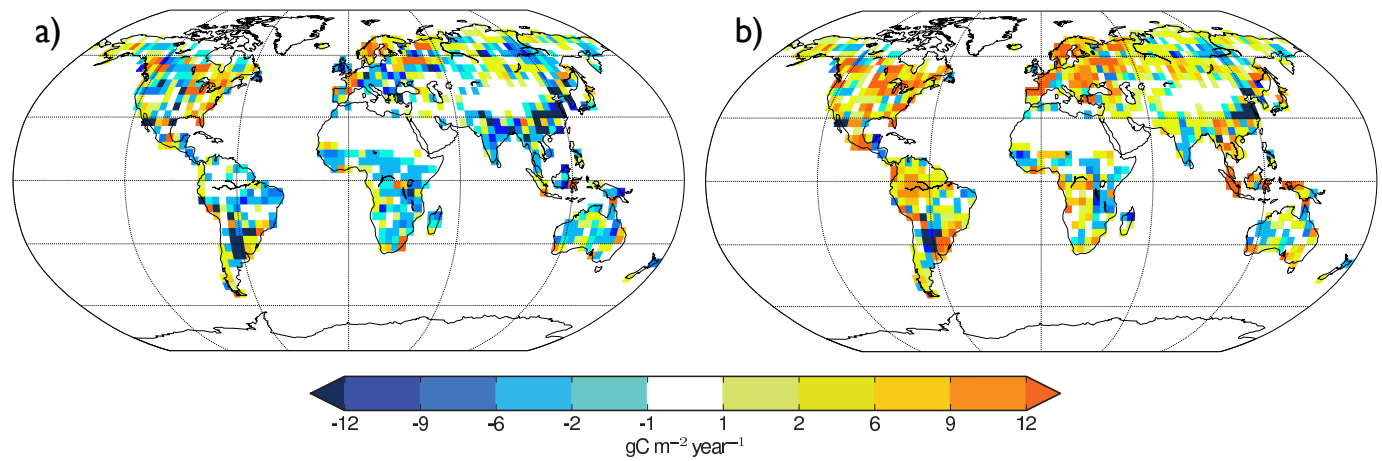

Fig. 5. Difference in the simulated atmosphere-land $\mathrm{CO}_{2}$ flux averaged over the 1959-2005 period between the mosaic and composite approaches for (a) the Climate $+\mathrm{CO}_{2}$ run and (b) the Climate $+\mathrm{CO}_{2}+\mathrm{LUC}$ run. Negative values indicate the atmosphere-land $\mathrm{CO}_{2}$ flux is greater when using the composite approach; positive values indicate the atmosphere-land $\mathrm{CO}_{2}$ flux is greater for the mosaic approach.

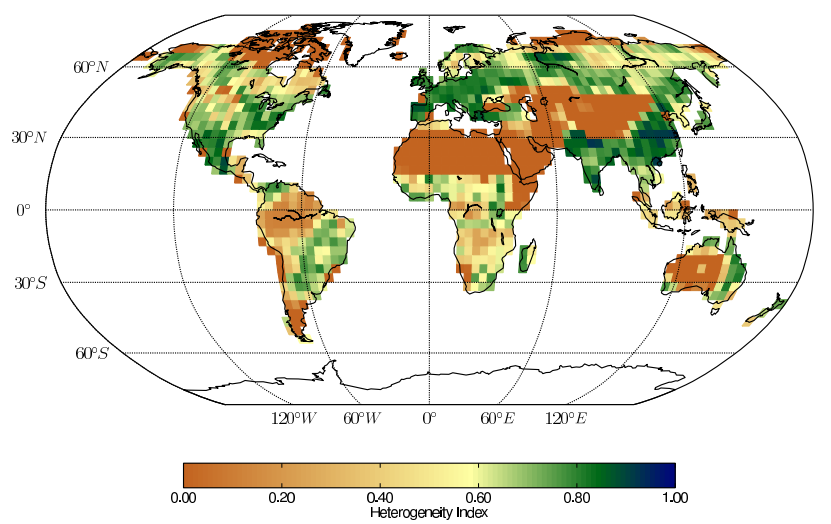

Fig. 6. Heterogeneity index for 1861 land cover based on the HYDE v 3.1 crop data set. This index is defined in Sect. 4 .

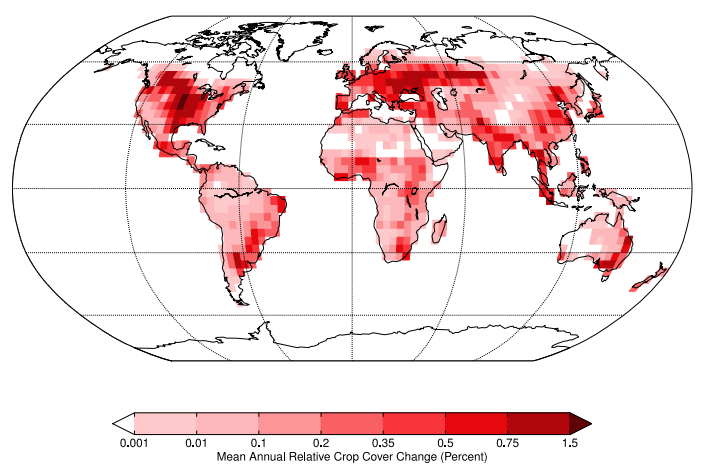

Fig. 7. Mean annual relative change in the crop cover, $\bar{R}_{\mathrm{C}}$, due to historical anthropogenic land use (1959-2005). This measure of land use change is defined in Sect. 4.

\section{Discussion}

CLASS-CTEM produces estimates of GPP, NPP, soil respiration, vegetation biomass, and litter and soil carbon mass that compare reasonably well with observational estimates and previous modelling studies of the pre-industrial period (Fig. 2 and Table 2) for both mosaic and composite configurations. The importance of the composite or mosaic approach in an equilibrium simulation on a global scale is minor, with the difference consistently $<5 \%$ for several model variables. However, the spatial differences are much greater and appear to be consistent across different model variables including GPP, vegetation biomass and soil C mass (Fig. 3). The differences between the mosaic and composite approaches are related to the representation of sub-grid scale variability of vegetation and the consequent manner in which grid-averaged energy and water balances evolve, leading to differences in net radiation absorbed by vegetation, soil temperature and moisture, etc., as illustrated in Li and Arora (2012). To aid interpretation of the differences between simulations using the mosaic and composite approaches, we derive a heterogeneity $(H)$ index as follows:

$H=1-\frac{\frac{1}{N-1} \sum_{i=1}^{N}\left(f_{i}-\bar{f}\right)^{2}}{\bar{f}}$,

where $f_{i}, i=1, N$ is the fractional coverage of a PFT as a function of the total vegetated fraction of the grid cell. For example, if one PFT covers $60 \%$ of a grid cell and a second PFT covers $20 \%$ with bare ground for the rest of the grid cell $(20 \%)$ then the values of $f_{i}$ are 0.75 and 0.25 for each PFT, respectively. $\bar{f}$ is the mean PFT fractional coverage. $N$ is the number of PFTs (nine in CTEM). Regions of high PFT heterogeneity (grid cells with many different PFTs) have $H$ index values close to 1 while regions of low PFT heterogeneity (grid cells with few PFTs present) are close to 0 . Eq. (4) yields an $H$ value of 1 if a grid cell contains $N$ PFTs and each occupies $(1 / N)$ th fraction of the grid cell, indicating maximum possible heterogeneity, and a value of 0 if an entire grid cell is occupied with only a single PFT. It is expected that the simulations using the composite and mosaic approaches will differ more in regions of high heterogeneity and less in areas of $H$ index closer to 0 . However, the 

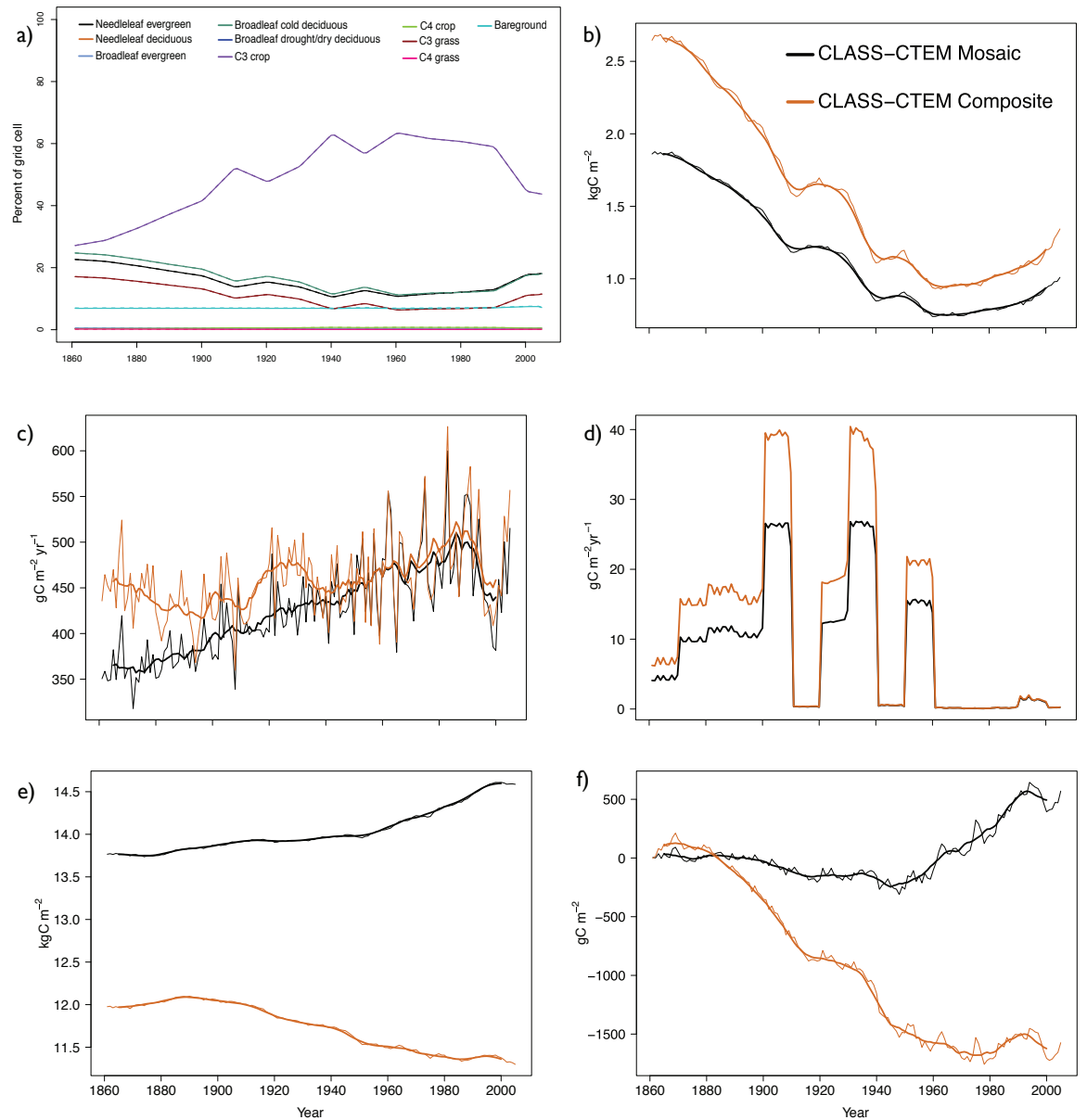

Fig. 8. CLASS-CTEM results for the mosaic and composite approaches for a grid cell at $50.10^{\circ} \mathrm{N}$ and $46.88^{\circ} \mathrm{E}$ (near Volgograd, Russia) from the Climate $+\mathrm{CO}_{2}+$ LUC simulation. (a) Specified changes in PFT fractional cover, (b) vegetation biomass, (c) net primary productivity (NPP), (d) total deforested biomass as a result of LUC, (e) soil C pool, and (f) total cumulative NBP $\left(\tilde{F}_{\mathrm{L}}\right)$. The model outputs have a $10 \mathrm{yr}$ running mean (thick lines) applied to the annual values (thin lines)

$\mathrm{H}$ index is not a prescriptive measure as it does not include information about a grid cell's climate and soil conditions. It is intended to highlight areas that could be expected to have greater differences between the composite and mosaic configurations due to PFT spatial representation. The global distribution of the $H$ index (based on 1861 land cover, used here with crop fraction based on the HYDE v 3.1 data set) is shown in Fig. 6. Areas of high $H$ index include parts of Mexico, Europe, China, India, eastern Australia, and the eastern US. Areas of low $H$ index include arid regions, such as central Australia; tropical regions, such as the Amazon; and the high north. Areas of low $H$ index are thus regions with vegetation biomass spread across very few PFTs.

Comparing the $H$ index (Fig. 6) to spatial differences between composite and mosaic simulations for the equilibrium simulation (Fig. 3) demonstrates a reasonable linkage. Areas of high $H$ index generally have higher GPP, vegetation biomass and soil carbon mass when the composite approach is used. Regions with moderate $H$ index values are not strongly biased towards either approach. Areas of low $H$ are generally similar in simulations using the composite and mosaic approaches, as expected. The differences between the model configurations evident in Fig. 3 are related to differences in the energy and water balances calculations in the two approaches, as noted by $\mathrm{Li}$ and Arora (2012). Li and Arora (2012) observed differences in net radiation flux (due to albedo differences); latent and sensible heat flux; and soil moisture and temperature between the composite and mosaic configurations, at their selected sites, when driven with identical climate. Net radiation and soil moisture directly influence photosynthesis and simulated canopy and soil temperatures influence respiratory fluxes.

Across the historical period (1959-2005) in the Climate $+\mathrm{CO}_{2}$ simulation, CLASS-CTEM simulates a global terrestrial $\mathrm{C}$ sink in-line with other model estimates and the land sink estimated by Le Quéré et al. (2013) (Fig. 5a). The difference between the global total mosaic and composite approaches estimated land $\mathrm{C}$ sink is small (ca. 5\%) (Fig. 4a), 


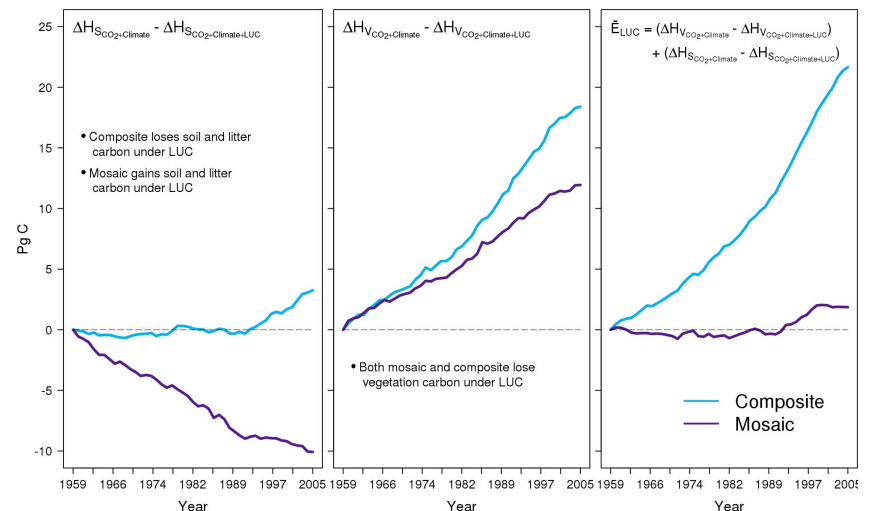

Fig. 9. Global response to LUC for the composite and mosaic approaches over the 1959-2005 period. The difference between the simulations with LUC (Climate $+\mathrm{LUC}+\mathrm{CO}_{2}$ ) and without LUC (Climate $+\mathrm{CO}_{2}$ ) for the cumulative change in the soil and litter $\left(\Delta H_{\mathrm{S}}\right)$ (left panel) and vegetation pools $\left(\Delta H_{\mathrm{S}}\right)$ (centre panel) are defined following Eq. (9). The cumulative LUC emissions ( $\left.\tilde{E}_{\text {LUC }}\right)$ for the composite and mosaic approaches is shown in the right panel as the additive result of the left and centre panel.

but can be large for different regions. The areas of largest disagreement for the estimated terrestrial C sink (without LUC effects) between the composite and mosaic simulations are generally regions of high $H$ index, with a few notable exceptions such as areas in the US Prairies (compare Figs. 5a and $6)$.

Incorporation of LUC has a marked impact on the difference in the estimated global terrestrial $\mathrm{C}$ sink (cumulative NBP; Fig. 4c) between the simulations using the mosaic and composite configurations. Our simulated deforested biomass across both configurations is lower than the bookkeeping estimate of Houghton et al. (2012) since we take into account only the changes in crop area, i.e. the effect of increasing pasture area over the historical period is not considered, and we do not account for wood harvesting and logging, shifting cultivation, and urbanization which is also not considered by Houghton et al. (2012). Land use change emissions are extremely difficult to quantify, with at least a $\pm 50 \%$ uncertainty (Houghton, 2003), and LUC is represented in TEMs and DGVMs using a range of parametrizations (e.g. see Brovkin et al., 2013).

LUC causes the estimated terrestrial $\mathrm{C}$ sink to drop by 21.4 Pg C when using the composite approach, as would be generally expected since LUC releases carbon from burning and decomposition of the deforested biomass. In the mosaic configuration, however, LUC causes the terrestrial sink to drop by only $1.2 \mathrm{PgC}$ (Fig. 4c; compare Climate $+\mathrm{CO}_{2}$ vs. Climate $+\mathrm{CO}_{2}+\mathrm{LUC}$ ), yielding a $16 \%$ difference in the estimated global terrestrial sink, over the 1959-2005 period, between the two approaches. The larger effect of LUC on the composite configuration's cumulative NBP, over the mosaic, appears to be widespread globally (Fig. 5b vs. 5a).
The LUC scheme in CLASS-CTEM removes natural vegetation when crop area increases. When LUC occurs, the amount of $\mathrm{C}$ that is burned or transferred to the litter and soil $\mathrm{C}$ pools depends on the vegetation biomass of the PFT that occupies that fraction of grid cell that is encroached upon at the time of LUC. In CLASS-CTEM, crops generally have a higher maximum photosynthetic rate than the natural vegetation they replace. However, crop productivity also depends on whether the mosaic or composite configuration is used. To interpret the differences between the mosaic and composite approaches, in the simulation with LUC, we define an additional measure that quantifies changes in crop fraction in a grid cell. The mean annual relative change in crop fraction, $\bar{R}_{\mathrm{C}}$, is calculated as

$\bar{R}_{\mathrm{C}}=\frac{\sum_{t=2}^{T}\left|f_{\mathrm{c}}(t)-f_{\mathrm{c}}(t-1)\right|}{T-1} \times 100 \%$,

where $f_{\mathrm{c}}(t)$ is the fractional crop area for a grid cell at time $t$ and $T$ is $47 \mathrm{yr}$, i.e. the period $1959-2005$. The $\bar{R}_{\mathrm{C}}$ over the 1959-2005 period is shown in Fig. 7. The major areas of LUC include the US Midwest and prairie region of Canada, eastern Europe, western Russia, and parts of northern India, China, southeast Australia and Argentina. While the $H$ index is arguably sufficient for interpreting the differences in the simulations with mosaic and composite configurations evident in Fig. 5a (Climate $+\mathrm{CO}_{2}$ ), i.e. in simulations without LUC, the contribution of both heterogeneity (Fig. 6) and LUC (Fig. 7) cause the differences in $\tilde{F}_{\mathrm{L}}$ between the composite and mosaic configurations visible in Fig. $5 \mathrm{~b}$ (Climate $\left.+\mathrm{CO}_{2}+\mathrm{LUC}\right)$. In general, areas of high $H$ index have greater visible differences between the mosaic and composite approaches, and these are then exaggerated by LUC processes, since the effect of LUC is influenced by the manner in which vegetation is represented.

To illustrate how the effect of LUC depends on representation of vegetation (using the composite or the mosaic approach) we show results from a grid cell that is representative of regions with high $H$ index and high LUC (Fig. 8) over the simulated historical period (1861-2005). Grid cells with a high $H$ index demonstrate larger differences between mosaic and composite treatments, as already discussed, and areas of high LUC accentuates differences between the model approaches. In the grid cell chosen for this purpose $\left(50.10^{\circ} \mathrm{N}\right.$ and $46.88^{\circ} \mathrm{E}$, near Volgograd, Russia), there is a large LUC, as evident in a doubling of $\mathrm{C}_{3}$ crop fraction and a resulting reduction in the tree fraction, between 1861 and 2005 as seen in Fig. 8a. For this grid cell, the composite approach simulates a larger vegetation biomass in 1860 in the pre-industrial equilibrium simulation (Fig. 8b) due to a higher grid-averaged NPP (Fig. 8c). As the $\mathrm{C}_{3}$ crop fraction expands, the fraction of other PFTs is reduced and the grid-averaged vegetation biomass for both mosaic and composite simulations decreases (Fig. 8b). The amount of carbon deforested from 
the live vegetation pools differs between the composite and mosaic simulations (Fig. 8d), since the amount of biomass removed depends on the amount that is present, but overall with the same pattern. That is, despite the same changes in fractional coverage of PFTs between the approaches, the amount of natural vegetation deforested differs. Since the deforested biomass is larger in the composite approach, over the historical period, it simulates a steeper decline in gridaveraged vegetation biomass (Fig. 8b). The soil $\mathrm{C}$ pools are initially smaller for the composite configuration (Fig. 8e) due to higher soil temperatures (not shown) despite higher litter inputs associated with higher initial productivity (Fig. 8c) in the composite compared to the mosaic approach. As carbon is transferred to the soil C pool by LUC, the two configurations diverge further. Soil $\mathrm{C}$ mass decreases in the composite approach and increases in the mosaic approach. The decline in soil $\mathrm{C}$ mass in the composite approach is due to the faster rate of shrinking vegetation biomass (Fig. 8b) and diminishing amounts of biomass transferred, as well as warmer soils in the composite approach promoting faster decomposition. As crop area expands, the grid-averaged NPP in the mosaic configuration approaches that of the composite (Fig. 8c) due to a faster rate of increase of crop productivity (not shown). Recall that in the mosaic configuration crops are grown in their individual tile, while in the composite approach they share the same physical land surface climate, including soil moisture, as other PFTs. The net result is that the trajectory of the cumulative atmosphere-land $\mathrm{CO}_{2}$ flux $\left(\tilde{F}_{\mathrm{L}}\right)$ differs greatly between composite and mosaic for this grid cell (Fig. 8f). Over the 1861-2005 period, the composite approach yields a net source of $\mathrm{C}$, while the mosaic approach simulates the grid cell to be a $\mathrm{C}$ sink. The differences in simulated energy and water balances between the two approaches act in a manner such that in the mosaic approach, the increasing productivity associated with increasing crop area overcomes the resulting emissions from burning and decomposition of deforested biomass. The different responses of grid-averaged carbon balance in this grid cell illustrate how the net effect of global LUC can be quite different for the two approaches.

On a global scale, similar behaviour is observed across the 1959-2005 period as has been described for the example above. Cumulative LUC emissions ( $\left.\tilde{E}_{\mathrm{LUC}}\right)$ can be represented by rearranging Eqs. 3 and 2 in terms of changes in the vegetation biomass $\left(\Delta H_{\mathrm{V}}\right)$ and dead carbon (soil and litter, $\Delta H_{\mathrm{S}}$ ) pools for the simulations with LUC $\left(\mathrm{CO}_{2}+\right.$ Climate + LUC $)$ and without $\left(\mathrm{CO}_{2}+\right.$ Climate $)$. The cumulative atmosphere-land $\mathrm{CO}_{2}$ flux for the $\mathrm{CO}_{2}+$ Climate simulation, i.e. the NEP, is written as

$\tilde{F}_{\mathrm{Ln}}=\Delta H_{\mathrm{V}_{\mathrm{CO}_{2}+\text { Climate }}}+\Delta H_{\mathrm{S}_{\mathrm{CO}_{2}+\text { Climate }}}$.

The cumulative atmosphere-land $\mathrm{CO}_{2}$ flux for the $\mathrm{CO}_{2}+$ Climate $+\mathrm{LUC}$ simulation, i.e. the NBP, is written as

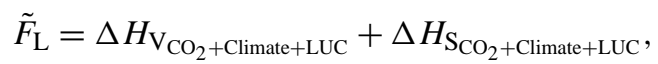

with $\tilde{E}_{\mathrm{LUC}}=\tilde{F}_{\mathrm{Ln}}-\tilde{F}_{\mathrm{L}}$ and rearranging Eqs. 6 and 7 we can solve for $\tilde{E}_{\mathrm{LUC}}$ as

$$
\begin{aligned}
\tilde{E}_{\mathrm{LUC}} & =\left(\Delta H_{\mathrm{V}_{\mathrm{CO}_{2}+\text { Climate }}}-\Delta H_{\mathrm{V}_{\mathrm{CO}_{2}+\text { Climate }+\mathrm{LUC}}}\right) \\
& +\left(\Delta H_{\mathrm{S}_{\mathrm{CO}_{2}+\text { Climate }}}-\Delta H_{\mathrm{S}_{\mathrm{CO}_{2}+\text { Climate }+\mathrm{LUC}}}\right),
\end{aligned}
$$

which shows that the $\tilde{E}_{\mathrm{LUC}}$ term consists of differences in live vegetation and dead litter and soil carbon pools from simulations with and without LUC. Figure 9 shows $\tilde{E}_{\text {LUC }}$ and its two components from the simulations using composite and mosaic approaches as a function of time for the period 1959-2005. The difference in the dead $\mathrm{C}$ pools for simulations with and without LUC $\left(\Delta H_{\mathrm{S}_{\mathrm{CO}_{2}+\text { Climate }}}-\right.$ $\left.\Delta H_{\mathrm{S}_{\mathrm{CO}_{2}+\text { Climate+LUC }}}\right)$ shows a divergent response between the composite and mosaic approaches. The composite approach loses soil and litter carbon under LUC, while the mosaic approach gains carbon (left panel of Fig. 9). This response is similar to that seen in the Russian grid cell discussed above. As the usual configuration of CLASS-CTEM uses the composite approach, this behaviour was not apparent until comparison was possible between the two approaches. The response of vegetation biomass to $\mathrm{LUC}\left(\Delta \mathrm{H}_{\mathrm{V}_{\mathrm{CO}_{2}+\text { Climate }}}\right.$

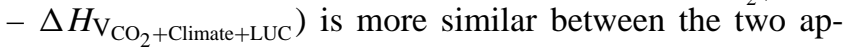
proaches with the expected loss of vegetation biomass due to LUC. The composite configuration loses more vegetation carbon than the mosaic configuration due to its higher preindustrial vegetation biomass (middle panel of Fig. 9). Taken together for an estimate of the cumulative LUC emissions over the 1959-2005 period ( $\tilde{E}_{\mathrm{LUC}}$ ), following Eq. (9), the gains in soil carbon in the mosaic approach negate much of the losses in vegetation biomass to give a small $\tilde{E}_{\mathrm{LUC}}$ while the composite approach shows higher $\tilde{E}_{\mathrm{LUC}}$ due to source contributions from both the dead and live carbon pools (right panel of Fig. 9).

The strong influence of the model vegetation spatial configuration has implications for model estimates of carbon emissions due to LUC. Estimates of the total LUC emissions range from $72 \mathrm{PgC}$ to $115.2 \mathrm{Pg} \mathrm{C}$ across the 1920 1999 period (Houghton et al., 2012). The CLASS-CTEM LUC parametrization gives a global LUC emissions estimate that is on the low end of other models. Arora and Boer (2010) estimate 73.6 PgC across the same time period from Table 1 in Houghton et al. (2012) using CLASS v. 2.7 with CTEM v. 1.0 in a composite configuration implemented in the first-generation Canadian Earth System Model (CanESM1) (Arora et al., 2009).

Our results suggest that the use of the mosaic configuration will yield an even lower estimate of LUC emissions. The sensitivity of modelled LUC emissions to spatial representation of vegetation makes the task of modelling LUC emissions in TEMs and DGVMs somewhat more difficult, given the already uncertain LUC emissions and the wide variety of parametrizations from which LUC emissions are modelled. It is difficult to definitively conclude which approach is better, mosaic or composite, as our results only illustrate that 
Table A1. CTEM parameter values updated in v 1.2 over v 1.0 (Arora and Boer, 2005) of maximum rate of carboxylation by the enzyme Rubisco, $V_{\text {c, max }}$ (Rogers, 2013), leaf maintenance respiration, and litter and soil carbon respiration rate.

\begin{tabular}{lcccc}
\hline PFT & $\begin{array}{c}V_{\mathrm{c}, \max } \\
\left(10^{-6} \mathrm{~mol} \mathrm{CO}\right) \\
\mathrm{m}^{-2} \mathrm{~s}^{-1}\end{array}$ & $\begin{array}{c}\text { Leaf maintenance } \\
\text { respiration } \\
\text { coefficient } \\
\text { (unitless) }\end{array}$ & $\begin{array}{c}\text { Litter respiration } \\
\text { rate at } 15^{\circ} \mathrm{C} \\
\left(\mathrm{kg} \mathrm{Ckg}^{-1} \mathrm{C} \mathrm{yr}^{-1}\right)\end{array}$ & $\begin{array}{c}\text { Soil carbon } \\
\text { respiration rate } \\
\text { at } 15^{\circ} \mathrm{C} \\
\left(\mathrm{kgCkg}^{-1} \mathrm{C} \mathrm{yr}^{-1}\right)\end{array}$ \\
\hline Needle-leaved evergreen & 35 & 0.015 & 0.4453 & 0.0260 \\
Needle-leaved deciduous & 40 & 0.017 & 0.5986 & 0.0260 \\
Broadleaf evergreen & 51 & 0.020 & 0.6339 & 0.0208 \\
Broadleaf cold deciduous & 67 & 0.015 & 0.7576 & 0.0208 \\
Broadleaf drought/dry deciduous & 40 & 0.015 & 0.6957 & 0.0208 \\
$\mathrm{C}_{3}$ crop & 55 & 0.015 & 0.6000 & 0.0350 \\
$\mathrm{C}_{4}$ crop & 40 & 0.025 & 0.6000 & 0.0350 \\
$\mathrm{C}_{3}$ grass & 75 & 0.013 & 0.5260 & 0.0125 \\
$\mathrm{C}_{4}$ grass & 15 & 0.025 & 0.5260 & 0.0125 \\
\hline
\end{tabular}

model architecture can have a significant influence on modelled LUC emissions.

\section{Conclusions}

Dynamic vegetation models must represent the sub-grid heterogeneity of terrestrial vegetation in a manner that is computationally efficient and best captures vegetation dynamics. The two possible extremes of the manner in which vegetation sub-grid spatial variability may be represented are the composite and mosaic approaches (Fig. 1). The impact of which model approach to use to best represent PFT spatial heterogeneity has not been adequately investigated previously. Here, we have used global simulations of the terrestrial carbon budget over the historical period to illustrate the effect of using the composite versus the mosaic approach.

In our equilibrium spin-up simulations using CLASSCTEM, in either the composite or mosaic configurations, we see no large differences in the global sums of model variables like vegetation biomass, GPP, NPP, soil C and litter mass between the two approaches $(<5 \%)$. However, spatially, the differences between the two approaches can be large for these model variables $(>30 \%)$. These differences are most apparent in regions with high heterogeneity of land cover (with regard to the number of PFTs) where the mosaic and composite representations are less comparable. In transient simulations, the mosaic and composite approaches respond differently to changing climate and $\mathrm{CO}_{2}$. The difference in cumulative atmosphere-land $\mathrm{CO}_{2}$ flux is $5 \mathrm{PgC}$, or around $5 \%$, over the 1959-2005 period in Climate $+\mathrm{CO}_{2}$ simulations. When LUC is accounted for, the difference between the cumulative atmosphere-land $\mathrm{CO}_{2}$ flux in the simulations using the composite and mosaic configuration increases to 15.2 Pg C (or around 16\%) and spatial differences increase further. The diagnosed LUC emissions, calculated as the difference between cumulative atmosphere-land $\mathrm{CO}_{2}$ flux from simulations with and without LUC, are 21.4 PgC and 1.2 $\mathrm{PgC}$ for the composite and mosaic approaches, respectively. These estimates are much lower than Houghton et al. (2012) since we do not account for changes in pasture area, wood harvesting, or shifting cultivation. CLASS-CTEM also treats crop PFTs explicitly, rather than using grass PFTs in place of crops as is common among most ESMs (Brovkin et al., 2013). In CLASS-CTEM, the high maximum photosynthesis rate of crops contributes to the higher rate of NPP increase as croplands expand and as $\mathrm{CO}_{2}$ increases and this acts to lower estimated LUC emissions in the mosaic approach. Irrespective of comparison with the Houghton et al. (2012) estimate, our results show that the difference between the two approaches of representing sub-grid heterogeneity of vegetation is largest when LUC is accounted for in conjunction with increasing $\mathrm{CO}_{2}$ and changing climate. The CLASSCTEM LUC scheme is sensitive to the vegetation productivity and biomass in a grid cell. Since the energy and water balances evolve differently in composite vs. mosaic configuration (as noted in Li and Arora, 2012), the same location can have a completely different evolution of its vegetation depending on the model configuration. This divergent evolution between model configurations leads to the large spatial differences in vegetation biomass and, if LUC is accounted for, in the amount of natural vegetation mass that is deforested.

An important application of dynamic vegetation models has been to estimate the size of the terrestrial land sink (Huntzinger et al., 2012; Le Quéré et al., 2013) and to estimate the contribution of LUC emissions to the global $\mathrm{C}$ budget (McGuire et al., 2001). Our results indicate that any estimates of LUC emissions obtained from dynamic vegetation models can be potentially influenced by the choice of subgrid scale spatial representation of the land surface. Since it is not readily apparent which representation (mosaic or composite) is more appropriate, care should be taken in interpreting model estimates of LUC emissions. 


\section{Copyright statement}

This work is distributed under the Creative Commons Attribution 3.0 License together with an author copyright. This license does not conflict with the regulations of the Crown Copyright.

Acknowledgements. We thank S. Griffith for his assistance in preparing the CRU-NCEP climate files. N. Steiner, D. Verseghy, and P. Bartlett provided helpful comments on an earlier version of the manuscript. J. R. Melton was supported by an NSERC Visiting Postdoctoral Fellowship. We wish to thank two anonymous referees whose careful comments greatly improved our manuscript.

Edited by: P. Stoy

\section{References}

Ajtay, M. J., Ketner, P., and Duvigneaud, P.: Terrestrial primary production and phytomass, in: The Global Carbon Cycle, SCOPE 13, edited by: Bolin, B., Degens, E. T., and Ketner, P., John Wiley \& Sons, New York, 129-182, 1979.

Arora, V. K.: Land surface modelling in general circulation models: A hydrological perspective, Ph.D. thesis, Department of Civil and Environmental Engineering, University of Melbourne, Chapter 6, 1997.

Arora, V. K.: Modeling vegetation as a dynamic component in soil-vegetation-atmosphere transfer schemes and hydrological models, Rev. Geophys., 40, 1-26, doi:10.1029/2001RG000103, 2002.

Arora, V. K.: Simulating energy and carbon fluxes over winter wheat using coupled land surface and terrestrial ecosystem models, Agr. Forest Meteorol., 118, 21-47, doi:10.1016/S01681923(03)00073-X, 2003.

Arora, V. K. and Boer, G. J.: A parameterization of leaf phenology for the terrestrial ecosystem component of climate models, Glob. Change Biol., 11, 39-59, doi:10.1111/j.13652486.2004.00890.x, 2005.

Arora, V. K. and Boer, G. J.: Uncertainties in the 20th century carbon budget associated with land use change, Glob. Change Biol., 16, 3327-3348, doi:10.1111/j.1365-2486.2010.02202.x, 2010.

Arora, V. K., Boer, G. J., Christian, J. R., Curry, C. L., Denman, K. L., Zahariev, K., Flato, G. M., Scinocca, J. F., Merryfield, W. J., and Lee, W. G.: The effect of terrestrial phtosynthesis down regulation on the twentieth-century carbon budget simulated with the CCCma Earth System Model, J. Climate, 22, 6066-6088, doi:10.1175/2009JCLI3037.1, 2009.

Arora, V. K., Scinocca, J. F., Boer, G. J., Christian, J. R., Denman, K. L., Flato, G. M., Kharin, V. V., Lee, W. G., and Merryfield, W. J.: Carbon emission limits required to satisfy future representative concentration pathways of greenhouse gases, Geophys. Res. Lett., 38, L05805 doi:10.1029/2010GL046270, 2011.

Beer, C., Reichstein, M., Tomelleri, E., Ciais, P., Jung, M., Carvalhais, N., Rödenbeck, C., Arain, M. A., Baldocchi, D., Bonan, G. B., Bondeau, A., Cescatti, A., Lasslop, G., Lindroth, A., Lomas, M., Luyssaert, S., Margolis, H., Oleson, K. W., Roupsard, O., Veenendaal, E., Viovy, N., Williams, C., Woodward, F. I., and Papale, D.: Terrestrial gross carbon dioxide up- take: global distribution and covariation with climate, Science, 329, 834-838, doi:10.1126/science.1184984, 2010.

Brovkin, V., Boysen, L., Arora, V. K., Boisier, J. P., Cadule, P., Chini, L., Claussen, M., Friedlingstein, P., Gayler, V., van den Hurk, B. J. J. M., Hurtt, G. C., Jones, C. D., Kato, E., de NobletDucoudrè, N., Pacifico, F., Pongratz, J., and Weiss, M.: Effect of anthropogenic land-use and land cover changes on climate and land carbon storage in CMIP5 projections for the 21st century, J. Climate, 26, 6859-6881, doi:10.1175/JCLI-D-12-00623.1, 2013.

Chapin, F. S., III, Woodwell, G. M., Randerson, J. T., Rastetter, E. B., Lovett, G. M., Baldocchi, D. D., Clark, D. A., Harmon, M. E., Schimel, D. S., Valentini, R., Wirth, C., Aber, J. D., Cole, J. J., Goulden, M. L., Harden, J. W., Heimann, M., Howarth, R. W., Matson, P. A., McGuire, A. D., Melillo, J. M., Mooney, H. A., Neff, J. C., Houghton, R. A., Pace, M. L., Ryan, M. G., Running, S. W., Sala, O. E., Schlesinger, W. H. and Schulze, E.-D.: Reconciling Carbon-cycle Concepts, Terminology, and Methods, Ecosystems, 9, 1041-1050, 2006.

Dickinson, R. E., Henderson-Sellers, A., and Kennedy, P.: Biosphere/Atmosphere Transfer Scheme (BATS) Version 1e as coupled to the NCAR Community Climate Model, Tech. rep., Climate and Global Dynamics Division, National Center for Atmospheric Research, Boulder, Colorado, 1993.

Essery, R. L. H., Best, M. J., Betts, R. A., Cox, P. M., and Taylor, C. M.: Explicit representation of subgrid heterogeneity in a GCM land surface scheme, J. Hydrometeorol., 4, 530-543, doi:10.1175/1525-7541(2003)004<0530:EROSHI>2.0.CO;2, 2003.

FAO/IIASA/ISRIC/ISS-CAS/JRC: Harmonized World Soil Database (version 1.2), 2012.

Friedlingstein, P., Cox, P., Betts, R., Bopp, L., von Bloh, W., Brovkin, V., Cadule, P., Doney, S., Eby, M., Fung, I., Bala, G., John, J., Jones, C., Joos, F., Kato, T., Kawamiya, M., Knorr, W., Lindsay, K., Matthews, H. D., Raddatz, T., Rayner, P., Reick, C., Roeckner, E., Schnitzler, K.-G., Schnur, R., Strassmann, K., Weaver, A. J., Yoshikawa, C. and Zeng, N.: Climate-Carbon Cycle Feedback Analysis: Results from the C4MIP Model Intercomparison, J. Clim., 19, 3337-3353, doi:10.1175/JCLI3800.1, 2006.

Gerber, S., Joos, F. and Prentice, I. C.: Sensitivity of a dynamic global vegetation model to climate and atmospheric $\mathrm{CO}_{2}$, Glob. Chang. Biol., 10, 1223-1239, doi:10.1111/j.15298817.2003.00807.x, 2004.

Houghton, R. A.: Revised estimates of the annual net flux of carbon to the atmosphere from changes in land use and land management 1850-2000, Tellus B Chem. Phys. Meteorol., 55, 378-390, 2003.

Houghton, R. A., House, J. I., Pongratz, J., van der Werf, G. R., DeFries, R. S., Hansen, M. C., Le Quéré, C., and Ramankutty, N.: Carbon emissions from land use and land-cover change, Biogeosciences, 9, 5125-5142, doi:10.5194/bg-9-5125-2012, 2012.

Huntzinger, D., Post, W., Wei, Y., Michalak, A., West, T., Jacobson, A., Baker, I., Chen, J., Davis, K., Hayes, D., Hoffman, F., Jain, A., Liu, S., McGuire, A., Neilson, R., Potter, C., Poulter, B., Price, D., Raczka, B., Tian, H., Thornton, P., Tomelleri, E., Viovy, N., Xiao, J., Yuan, W., Zeng, N., Zhao, M., and Cook, R.: North American Carbon Program (NACP) regional interim synthesis: terrestrial biospheric model intercomparison, Ecol. 
Model., 232, 144-157, doi:10.1016/j.ecolmodel.2012.02.004, 2012.

Hurtt, G. C., Chini, L. P., Frolking, S., Betts, R. A., Feddema, J., Fischer, G., Fisk, J. P., Hibbard, K., Houghton, R. A., Janetos, A., Jones, C. D., Kindermann, G., Kinoshita, T., Goldewijk, K. K., Riahi, K., Shevliakova, E., Smith, S., Stehfest, E., Thomson, A., Thornton, P., van Vuuren, D. P., and Wang, Y. P.: Harmonization of land-use scenarios for the period 1500-2100: 600 years of global gridded annual land-use transitions, wood harvest, and resulting secondary lands, Clim. Change, 109, 117161, doi:10.1007/s10584-011-0153-2, 2011.

Koster, R. D. and Suarez, M. J.: Modeling the land surface boundary in climate models as a composite of independent vegetation stands, J. Geophys. Res.-Atmos., 97, 2697-2715, doi:10.1029/91JD01696, 1992a.

Koster, R. D. and Suarez, M. J.: A comparative analysis of two land surface heterogeneity representations, J. Climate, 5, 1379-1390, 1992b.

Le Quéré, C., Raupach, M. R., Canadell, J. G., Marland, G., Bopp, L., Ciais, P., Conway, T. J., Doney, S. C., Feely, R. A., Foster, P., Friedlingstein, P., Gurney, K., Houghton, R. A., House, J. I., Huntingford, C., Levy, P. E., Lomas, M. R., Majkut, J., Metzl, N., Ometto, J. P., Peters, G. P., Colin Prentice, I., Randerson, J. T., Running, S. W., Sarmiento, J. L., Schuster, U., Sitch, S., Takahashi, T., Viovy, N., van der Werf, G., and Woodward, F. I.: Trends in the sources and sinks of carbon dioxide, Nat. Geosci., 2, 831-836, doi:10.1038/ngeo689, 2009.

Le Quéré, C., Andres, R. J., Boden, T., Conway, T., Houghton, R. A., House, J. I., Marland, G., Peters, G. P., van der Werf, G. R., Ahlström, A., Andrew, R. M., Bopp, L., Canadell, J. G., Ciais, P., Doney, S. C., Enright, C., Friedlingstein, P., Huntingford, C., Jain, A. K., Jourdain, C., Kato, E., Keeling, R. F., Klein Goldewijk, K., Levis, S., Levy, P., Lomas, M., Poulter, B., Raupach, M. R., Schwinger, J., Sitch, S., Stocker, B. D., Viovy, N., Zaehle, S., and Zeng, N.: The global carbon budget 1959-2011, Earth Syst. Sci. Data, 5, 165-185, doi:10.5194/essd-5-165-2013, 2013.

Li, R. and Arora, V. K.: Effect of mosaic representation of vegetation in land surface schemes on simulated energy and carbon balances, Biogeosciences, 9, 593-605, doi:10.5194/bg-9-593-2012, 2012.

McGuire, A. D., Sitch, S., Clein, J. S., Dargaville, R., Esser, G., Foley, J., Heimann, M., Joos, F., Kaplan, J., Kicklighter, D. W., Meier, R. A., Melillo, J. M., Moore, B., Prentice, I. C., Ramankutty, N., Reichenau, T., Schloss, A., Tian, H., Williams, L. J., and Wittenberg, U.: Carbon balance of the terrestrial biosphere in the twentieth century: analyses of $\mathrm{CO}_{2}$, climate and land use effects with four processbased ecosystem models, Global Biogeochem. Cy., 15, 183-206, doi:10.1029/2000GB001298, 2001.

Meinshausen, M., Smith, S. J., Calvin, K., Daniel, J. S., Kainuma, M. L. T., Lamarque, J.-F., Matsumoto, K., Montzka, S. A., Raper, S. C. B., Riahi, K., Thomson, A., Velders, G. J. M., and van Vuuren, D. P.: The RCP greenhouse gas concentrations and their extensions from 1765 to 2300 , Climatic Change, 109, 213-241, doi:10.1007/s10584-011-0156-z, 2011.
Molod, A. and Salmun, H.: A global assessment of the mosaic approach to modeling land surface heterogeneity, J. Geophys. Res.Atmos., 107, 9-1-9-18, doi:10.1029/2001JD000588, 2002.

Molod, A., Salmun, H., and Waugh, D. W.: A new look at modeling surface heterogeneity: Extending its influence in the vertical, J. Hydrometeorol., 4, 810-825, doi:10.1175/15257541(2003)004<0810:ANLAMS>2.0.CO;2, 2003.

Molod, A., Salmun, H., and Waugh, D. W.: The impact on a GCM climate of an extended mosaic technique for the land-atmosphere coupling, J. Climate, 17, 3877-3891, doi:10.1175/1520-0442(2004)017<3877:TIOAGC>2.0.CO;2, 2004.

Oleson, K. W., Lawrence, D. M., Bonan, G., Flanner, M. G., Kluzek, E., Levis, S., Swenson, S. C., Thornton, P. E., Dai, A., Decker, M., Dickinson, R., Feddema, J., Heald, C. L., Hoffman, F., Lamarque, J.-F., Mahowald, N., Niu, G.-Y., Qian, T., Randerson, J., Running, S., Sakaguchi, K., Slater, A., Stöckli, R., Wang, A., Yang, Z.-L., Zeng, X., and Zeng, X.: Technical Description of version 4.0 of the Community Land Model (CLM), Tech. rep., Climate and Global Dynamics Division, National Center for Atmospheric Research, Boulder, Colorado, 2010.

Peng, Y., Arora, V. K., Kurz, W. A., Hember, R. A., Hawkins, B., Fyfe, J. C., and Werner, A. T.: Climate and atmospheric drivers of historical terrestrial carbon uptake in the province of British Columbia, Canada, Biogeosciences Discuss., 10, 13603-13638, doi:10.5194/bgd-10-13603-2013, 2013.

Post, W. M., Emanuel, W. R., Zinke, P. J., and Stangenberger, A. G.: Soil carbon pools and world life zones, Nature, 298, 156-159, doi:10.1038/298156a0, 1982.

Raich, J. W. and Potter, C. S.: Global patterns of carbon dioxide emissions from soils, Global Biogeochem. Cy., 9, 23-36, doi:10.1029/94GB02723, 1995.

Raich, J. W. and Schlesinger, W. H.: The global carbon dioxide flux in soil respiration and its relationship to vegetation and climate, Tellus B, 44, 81-99, doi:10.1034/j.1600-0889.1992.t01-100001.x, 1992.

Rogers, A.: The use and misuse of $V_{\mathrm{c}, \max }$ in earth system models, Photosynth. Res., doi:10.1007/s11120-013-9818-1, 2013.

Ruesch, A. and Holly, K.: New IPCC Tier-1 Global Biomass Carbon Map For the Year 2000, available from: ftp://cdiac.ornl.gov/pub/ global_carbon/ (last access: 10 September 2012), 2008.

Running, S. W., Nemani, R. R., Heinsch, F. A., Zhao, M., Reeves, M., and Hashimoto, H.: A continuous satellitederived measure of global terrestrial primary production, BioScience, 54, 547-560, doi:10.1641/00063568(2004)054[0547:ACSMOG]2.0.CO;2, 2004.

Saugier, B., Roy, J., and Mooney, H. A.: Estimations of global terrestrial productivity: converging towards a single number?, in: Terrestrial Global Productivity, edited by: Roy, J., Saugier, B., and Mooney, H. A., Physiological Ecology, Academic Press, San Diego, California, 543-558, 2001.

Schlesinger, W. H.: Carbon balance in terrestrial detritus, Annu. Rev. Ecol. Syst., 8, 51-81, doi:10.1146/annurev.es.08.110177.000411, 1977.

Sellers, P. J., Mintz, Y., Sud, Y. C., and Dalcher, A.: A Simple Biosphere Model (SIB) for use within general circulation models, J. Atmos. Sci., 43, 505-531, doi:10.1175/15200469(1986)043<0505:ASBMFU>2.0.CO;2, 1986. 
Sitch, S., Smith, B., Prentice, I. C., Arneth, A., Bondeau, A., Cramer, W., Kaplan, J. O., Levis, S., Lucht, W., Sykes, M. T., Thonicke, K., and Venevsky, S.: Evaluation of ecosystem dynamics, plant geography and terrestrial carbon cycling in the LPJ dynamic global vegetation model, Glob. Change Biol., 9, 161-185, doi:10.1046/j.1365-2486.2003.00569.x, 2003.

Verseghy, D. L.: CLASS - a Canadian land surface scheme for GCMs I. Soil model, Int. J. Climatol., 11, 111-133, doi:10.1002/joc.3370110202, 1991.

Verseghy, D.: CLASS - the Canadian Land Surface Scheme (Version 3.4), Technical Documentation, Tech. rep., Science and Technology Branch, Environment Canada, 2009.

Verseghy, D.: CLASS - the Canadian Land Surface Scheme (Version 3.6), Technical Documentation, Tech. rep., Science and Technology Branch, Environment Canada, 2012.
Verseghy, D. L., McFarlane, N. A., and Lazare, M.: CLASS - a Canadian land surface scheme for GCMs, II. Vegetation model and coupled runs, Int. J. Climatol., 13, 347-370, doi:10.1002/joc.3370130402, 1993.

Viovy, N.: CRU-NCEP Version 4, available at: http://dods.extra.cea. fr/data/p529viov/cruncep (last access: 11 October 2012), 2012.

Zhao, M., Running, S. W., and Nemani, R. R.: Sensitivity of moderate resolution imaging spectroradiometer (MODIS) terrestrial primary production to the accuracy of meteorological reanalyses, J. Geophys. Res.-Biogeo., 111, G01002, doi:10.1029/2004JG000004, 2006.

Zobler, L.: A World Soil File for Global Climate Modelling, 1986. 